

\section{Assessment of Biomass Resources in Liberia}

Assistance Program (LEAP)

Anelia Milbrandt

Prepared under Task No. WTD3.1000

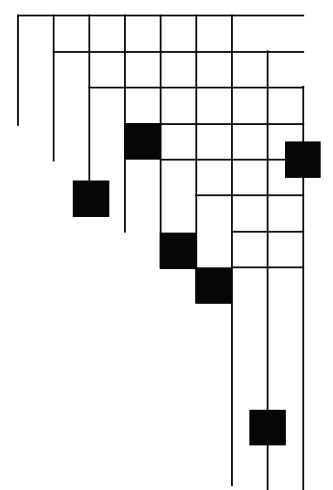




\section{NOTICE}

This report was prepared as an account of work sponsored by an agency of the United States government. Neither the United States government nor any agency thereof, nor any of their employees, makes any warranty, express or implied, or assumes any legal liability or responsibility for the accuracy, completeness, or usefulness of any information, apparatus, product, or process disclosed, or represents that its use would not infringe privately owned rights. Reference herein to any specific commercial product, process, or service by trade name, trademark, manufacturer, or otherwise does not necessarily constitute or imply its endorsement, recommendation, or favoring by the United States government or any agency thereof. The views and opinions of authors expressed herein do not necessarily state or reflect those of the United States government or any agency thereof.

Available electronically at http://www.osti.gov/bridge

Available for a processing fee to U.S. Department of Energy and its contractors, in paper, from:

U.S. Department of Energy

Office of Scientific and Technical Information

P.O. Box 62

Oak Ridge, TN 37831-0062

phone: 865.576 .8401

fax: 865.576 .5728

email: mailto:reports@adonis.osti.gov

Available for sale to the public, in paper, from:

U.S. Department of Commerce

National Technical Information Service

5285 Port Royal Road

Springfield, VA 22161

phone: 800.553 .6847

fax: 703.605.6900

email: orders@ntis.fedworld.gov

online ordering: http://www.ntis.gov/ordering.htm 


\section{Acknowledgments}

The author would like to thank the International Resources Group (IRG) staff for managing this project on behalf of the U.S. Agency for International Development USAID, and particularly Mr. Simba Mangwengwende, the project overseer, for his review and feedback. Thanks to Dr. Ralph Overend, retired NREL Research Fellow, for his review and valuable recommendations.

A special thanks to Kristin Stroup from the Energy and Security Group (ESG) for her invaluable contributions in the data gathering process. 


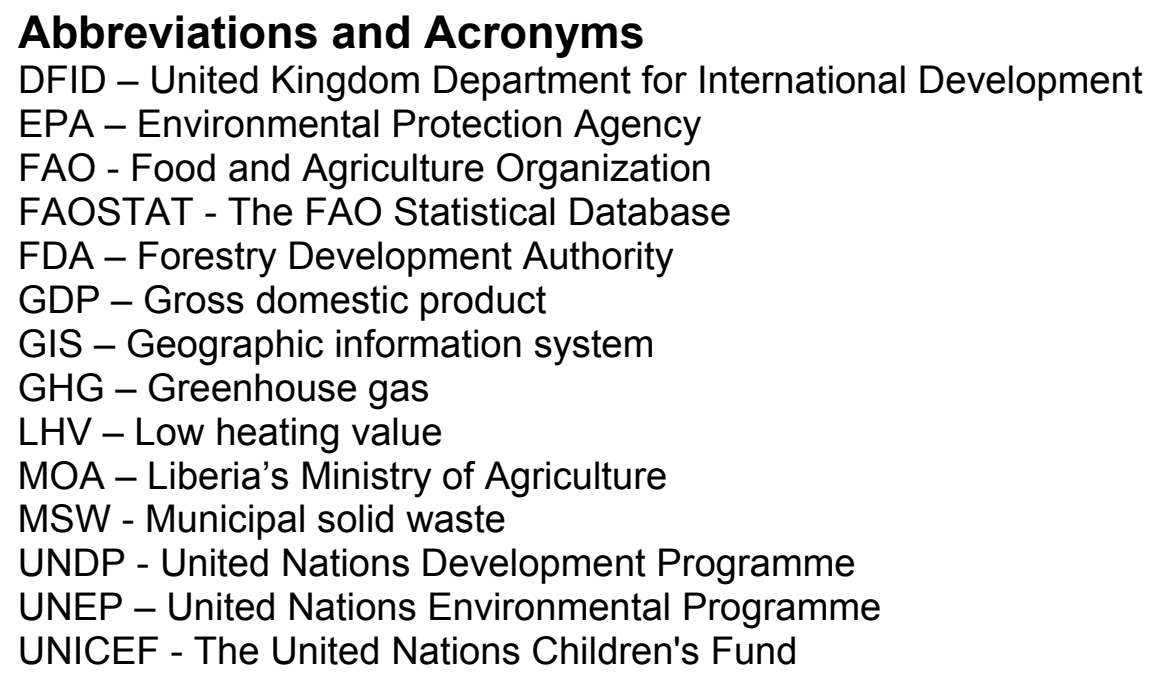

\section{Units of Measure}

dam $^{3}$ - cubic decameter or $1,000 \mathrm{~m}^{3}$ or $10^{6} \mathrm{~L}$, described in some sources as a ML (Megaliter) GWh - Gigawatt hour $\left(10^{9} \mathrm{Wh}\right)$

ha - hectare

$\mathrm{hm}^{3}$ - cubic hectometer or $1,000,000 \mathrm{~m}^{3}$ or $10^{9} \mathrm{~L}$, described in some sources as a GL (Gigaliter)

$\mathrm{kg}$ - kilogram

$\mathrm{kWh}-$ kilowatt hour $\left(10^{3} \mathrm{Wh}\right)$

$\mathrm{L}-$ liter (decimeter or $\mathrm{dm}^{3}$ )

$\mathrm{m}^{3}$ - cubic meter

Mt - Megatonne (10 6 tonnes)

MWh - Megawatt hour $\left(10^{6} \mathrm{Wh}\right)$

TJ - Terajoule $\left(10^{12} \mathrm{~J}\right)$

Tonne - metric ton

\section{Glossary of Plant Names}

African walnut (Lovoa klaineana)

Banana (Musa sp.)

Cacao (Theobroma cacao)

Cassava (Manihot esculenta)

Coconut Palm (Cocos nucifera)

Cocoyam (Colocasia esculenta)

Coffee (Rubiaceae family)

Jatropha (Jatropha Curcas)

Kola tree (Malvaceae sp.)

Mahogany (Swietenia mahagoni)

Maize (Zea mays)

Oil Palm (Elaeis guineensis)

Pineapple (Ananas comosus)

Plantain (Musa sp.)

Rubber Tree (Hevea brasiliensis)

Sugarcane (Poaceae sp.)

Yam (Dioscorea sp.) 


\section{Executive Summary}

Biomass resources meet about $99.5 \%$ of the Liberian population's energy needs so they are vital to basic welfare and economic activity. Already, traditional biomass products like firewood and charcoal are the primary energy source used for domestic cooking and heating. However, other more efficient biomass technologies are available that could open opportunities for agriculture and rural development, and provide other socio-economic and environmental benefits.

The main objective of this study is to estimate the biomass resources currently and potentially available in the country and evaluate their contribution for power generation and the production of transportation fuels. It intends to inform policy makers and industry developers of the biomass resource availability in Liberia, identify areas with high potential, and serve as a base for further, more detailed site-specific assessments.

A variety of biomass resources exist in the country in large quantities and with opportunities for expansion. The study found that these resources are more than enough to cover the country's annual electricity consumption of $297 \mathrm{GWh}$ and oil consumption of $206 \mathrm{dam}^{3}$. While the contribution of food crop residues, animal manure, and municipal solid waste is small in comparison to other resources at a national level, they could play a valuable role in stand-alone electricity applications and be particularly effective for households in remote rural areas. On the other hand, cash crop and forest residues, resulting mainly from medium and large enterprises, provide opportunities for large-scale centralized power generation.

The study considers potential biomass resources and the expansion of key existing resources, such as oil palm, coconut, and sugarcane, to evaluate their fuel and power production potential on available cropland. It is unrealistic to assume that all of this land would be used for cash crop cultivation. A portion of it may go under afforestation to maintain forest ecosystems and their unique biodiversity, or be used for food crops production and other agricultural activities, or be converted to urban land. Therefore, the study evaluates the fuel and power production potential of biomass resources under three scenarios: using $10 \%, 25 \%$, and $50 \%$ of the available cropland for cash crop expansion.

The local production and use of biomass resources as substitute for fossil-based fuels offers many socio-economic and environmental benefits for Liberia including energy security, investment opportunities, job creation, rural development, decreased greenhouse gas (GHG) emissions, waste utilization, and erosion control. However, if not managed properly, biomass resource development could have negative impacts, particularly to the environment. These include deforestation, increased GHG emissions, loss of biodiversity, and soil erosion. The socio-economic and environmental implications briefly described in this paper should form the basis of a more detailed study on the impact of biomass resources development in order to guide appropriate national policies and measures. 


\section{Table of Contents}

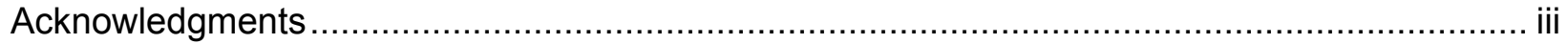

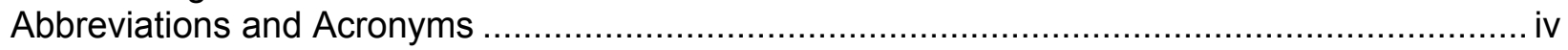

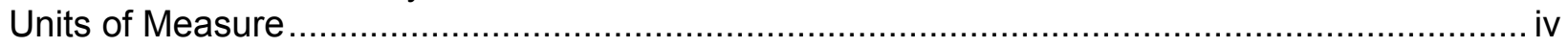

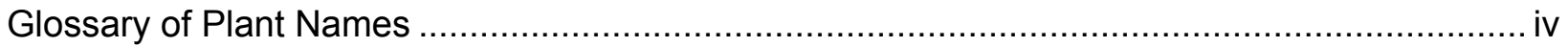

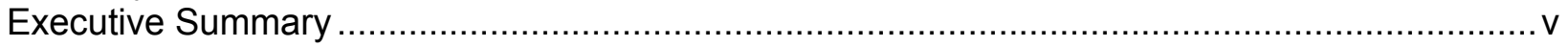

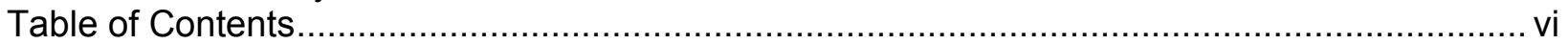

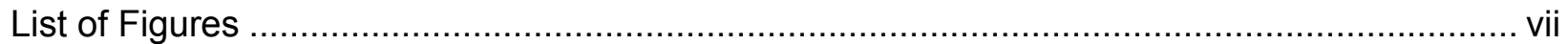

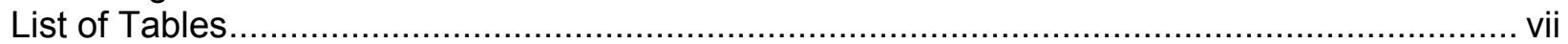

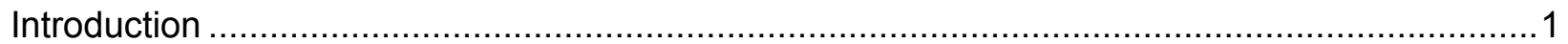

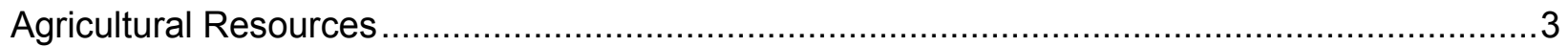

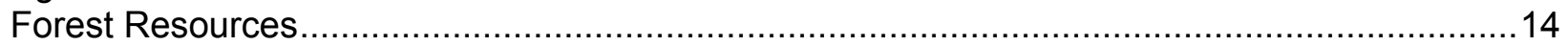

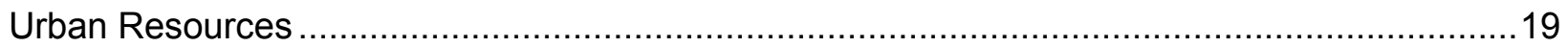

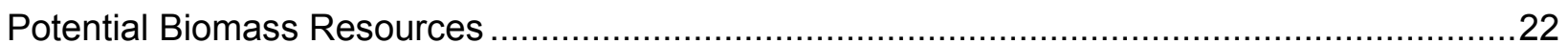

Socio-Economic and Environmental Implications of Biomass Resource Development

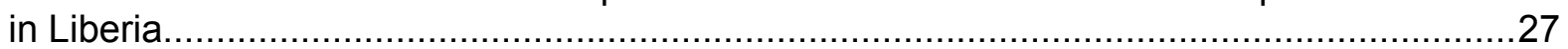

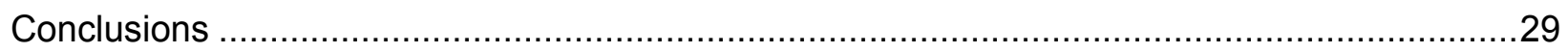

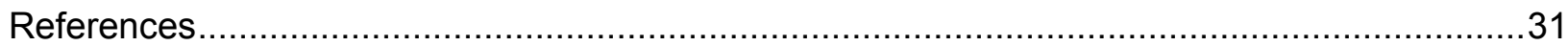

Appendix A. Estimating Food Crop Residues by County.............................................. 34

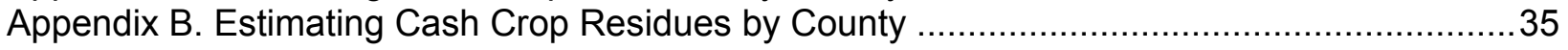

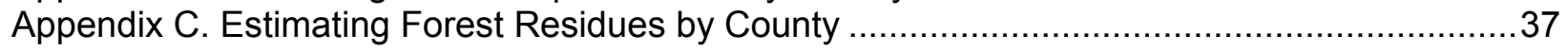




\section{List of Figures}

Figure 1. Food Crop Residues in Liberia by County .......................................................... 5

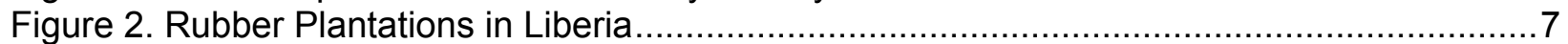

Figure 3. Oil Palm Plantations in Liberia ............................................................................. 10

Figure 4. Cash Crop Residues in Liberia by County ................................................... 13

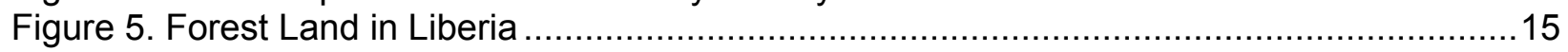

Figure 6. Areas Suitable for Logging Contracts in Liberia .............................................. 16

Figure 7. Forest Residues in Liberia by County ....................................................... 19

Figure 8. Municipal Solid Waste Generation in Major Urban Areas in Liberia .........................20

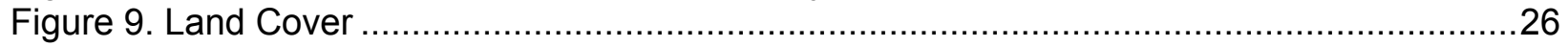

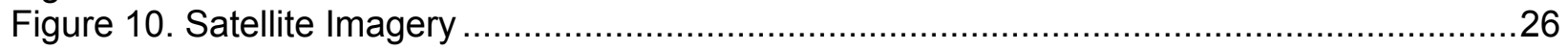

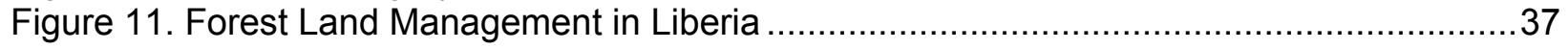

\section{List of Tables}

Table 1. Food Crop Residues in Liberia ........................................................................ 4

Table 2. Food Crop Residues in Liberia by County ........................................................... 4

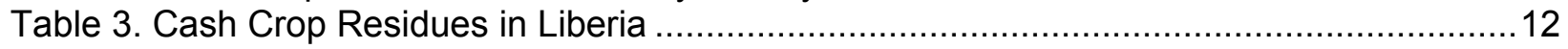

Table 4. Cash Crop Residues in Liberia by County ................................................. 12

Table 5. Animal Manure and Biogas Potential in Liberia ................................................ 14

Table 6. Logging Contracts in Liberia ......................................................................... 17

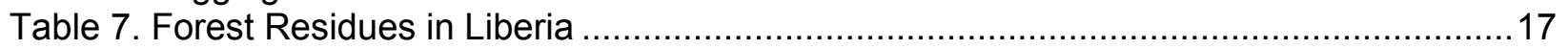

Table 8. Forest Residues in Liberia by County .......................................................... 18

Table 9. Municipal Solid Waste Generation and Electricity Potential in Major Urban Areas in

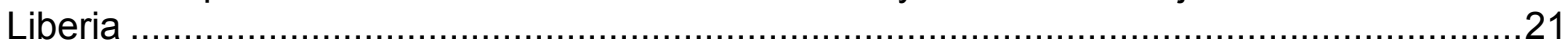

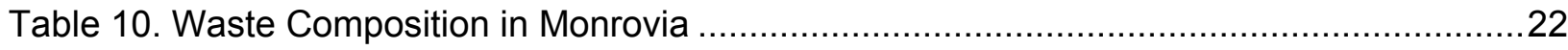

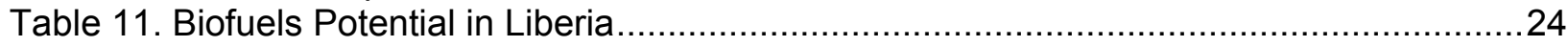

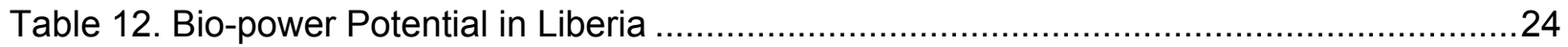

Table 13. Bio-power and Biofuels from Existing and Potential Biomass Resources ..................29

Table 14. Bio-power and Biofuels from Existing and Potential Biomass Resources by County .30

Table 15. Farming Families Growing Food Crops in Liberia, 2005 .......................................34

Table 16. Farming Families Growing Cash Crops in Liberia, 2005 ........................................35 


\section{Introduction}

Biomass energy is derived from plant-based material and residues where solar energy has been converted into organic matter. Biomass resources can be broadly classified into the following categories:

- Agricultural crops and residues;

- Dedicated energy crops (herbaceous and tree species);

- Forestry products and residues;

- Residues and byproducts from food, feed, fiber, wood, and materials processing plants [sawdust from sawmills, black liquor (a byproduct of paper making), cheese whey (a byproduct of cheese-making processes), and animal manure];

- Post-consumer residues and wastes, such as fats, greases, oils, construction and demolition wood debris and other urban wood wastes, municipal solid wastes and wastewater, and landfill gases.

There are competing uses for biomass resources because of their economic and environmental value. Biomass can be used to generate power, heat, steam, and for producing transportation fuels. Biomass is also used by the food processing industries, animal feed industry, and the wood products industry, which includes construction and fiber products (paper and derivatives); along with chemical products made by these industries that have diverse applications including detergents, fertilizers, and erosion control products.

In Liberia, as in nearly all of Sub-Sahara African countries, biomass (firewood, charcoal, and crop residues) is the primary energy source used for domestic cooking and heating. Up to 99.5\% of the population relies on biomass-based fuels according to the United Nations Development Programme (UNDP). Such an overwhelming and persistent dependence on biomass fuels is associated with severe environmental, health, and social implications, such as the destruction of forests, loss of biodiversity, soil erosion, indoor air pollution, and increased travel distances for resource collection. Liberia's economic recovery and population growth will lead to higher energy demand; therefore, managing and improving the production and consumption efficiency of biomass resources are key to sustainable development. Furthermore, introducing other alternative renewable energy sources like wind and solar, as well as further development of hydroelectricity would relieve the pressure on biomass resources in Liberia.

\section{Project Objectives and Approach}

This study intends to inform policy makers and industry developers of the biomass resource availability in Liberia, identify areas with high potential, and serve as a base for further, more detailed and site-specific assessments.

The project's objective is to estimate the biomass resources currently and potentially available in the country and evaluate their potential contribution for power generation and transportation fuels production. To accomplish this objective, agricultural, environmental, and socio-economic data are analyzed both statistically and graphically using geographic information systems (GIS). A GIS is a computer-based information system used to create, manipulate, and analyze geographic information. The results are presented in a tabular and geospatial format (maps) at a national, sub-national (county), and site-specific level.

The biomass resource estimates are based on numerous assumptions and factors that relate agricultural, industrial, and demographic statistics to the amount of residue generated. A detailed description of the methodology is provided throughout the document. For several 
plantation crops (cacao, rubber, coconut, and oil palm), for example, the study evaluates the contribution of a small portion (10\%) of all residues available after replanting, and suggests that only $30 \%$ of cacao pods and rubber leaves are collected as biomass (the rest should be left on the field to maintain soil quality and control erosion). Although these numbers are conservative and somewhat arbitrary, the users have all the information necessary to adjust assumptions and conversion factors for further evaluation of the biomass resource availability.

Detailed on-site analysis is recommended before developing any facilities; however, this analysis should be useful in refining the prospecting process of site identification. 


\section{Agricultural Resources}

\section{Overview of Agricultural Sector}

Liberia has immense agricultural potential with an estimated 3.7 million hectares of arable land ( $38 \%$ of the total land area), of which about $6 \%$ is currently cultivated (FRM 2004). About $60 \%$ of the country, situated in the moist belt along the coast of West Africa, is covered by forest and woodland. The rain forest soils, while well drained, are highly leached, making Liberia better adapted to tree crop agriculture than to annual field crop production.

The climate and terrain conditions in Liberia are very favorable for agricultural development. Due to abundant water resources in the country, irrigation infrastructure is virtually non-existent. The rainy season lasts from April to October with a very high annual rainfall, ranging from 1,600 $\mathrm{mm}$ inland to $4,600 \mathrm{~mm}$ on the coast. The terrain is mostly made up of flat to rolling coastal plains, running into some interior plateaus and low mountains in the northeast. The country is divided into four agro-ecological zones: coastal plains (up to $100 \mathrm{~m}$ above sea level), interior hills (100-300 m), interior plateaus (300-600 m), and mountainous areas (in excess of $600 \mathrm{~m}$ ).

Agriculture is the backbone of Liberia's economy, providing informal employment for more than $70 \%$ of the workforce (mostly in rural areas) and contributing an estimated $53 \%$ to the gross domestic product (GDP) in 2006 (MOA 2007 and ITTAS 2008). The agricultural sector was left in ruin after Liberia's 14-year civil war (which ended in 2003), and it is slowly starting to revive itself. The damage to the agricultural sector is manifested in low productivity of agricultural systems; disruption of production due to the displacement of farming communities; erosion of marketing systems due to road, transport, and processing infrastructure degradation; physical insecurity; lack of farming opportunities (including seeds and tools) in the areas of displacement; and socio-economic dislocation (FAO 2006).

The Ministry of Agriculture defines three agricultural production systems, differentiated by the scale of production (MOA 2007):

- Large plantations (between 800 and 40,000 ha) produce export crops from perennials such as rubber, oil palm, and to a lesser degree, coffee and cacao. This system can be sub-divided into the large commercial plantations that are owned and managed by the private sector (found particularly in the rubber and palm oil sectors) and the state-owned plantations run by the Liberian Palm Products Corporation and the Liberian Cocoa and Coffee Corporation. Production in this second group is limited, although they remain in existence.

- Domestically owned, medium-sized commercial farms (between 5 and 200 ha) produce industrial crops for export and the local market (although these farms are extremely small in number).

- Small household farms (average size of 1.2 ha), the livelihood of the rural population, make up the majority of all farming. They use traditional production techniques with extremely limited use of modern inputs. Household farms are based on family labor and concentrate on growing food crops like rice and cassava, with some growing cash crops like rubber, coffee, cacao, and oil palm.

\section{Food Crop Residues}

Liberia produces a variety of basic food crops, including rice (the staple food of the country), cassava, other roots and tubers (sweet potato, yam, and cocoyam), maize, vegetables, groundnuts, and pulses. After these crops have been harvested and processed, various residues and byproducts remain, such as stalks, straw, husks, and shells. No data have been 
published on the quantities of crop residues and agro-industrial byproducts produced in Liberia. However, based on crop production statistics, and using appropriate crop to residue ratios, it is estimated that some 125,000 tonnes of food crop residues are produced each year (Table 1). The corresponding energy content is about 2,100 TJ, equivalent to $188 \mathrm{GWh}$ of electricity. Leading counties include Nimba, Montserrado, and Bong (Table 2). The methodology for estimating the food crop residues by county is presented in Appendix A.

Table 1. Food Crop Residues in Liberia

\begin{tabular}{|c|c|c|c|c|c|c|c|c|}
\hline Commodity & $\begin{array}{c}\text { Production } \\
\text { (tonnes) }\end{array}$ & Residue Type & $\begin{array}{c}\text { Crop to Residue } \\
\text { Ratio }\end{array}$ & $\begin{array}{c}\text { Moisture } \\
\text { Content (\%) }\end{array}$ & $\begin{array}{c}\text { Residue } \\
\text { (dry tonnes) }\end{array}$ & $\begin{array}{c}\text { LHV } \\
(\mathrm{MJ} / \mathrm{kg})\end{array}$ & $\begin{array}{c}\text { Total } \\
\text { Energy } \\
(\mathrm{TJ} / \mathrm{yr})\end{array}$ & GWh \\
\hline \multirow{2}{*}{ Rice } & \multirow{2}{*}{110,000} & straw & 0.45 & 12.71 & 43,209 & 16 & 691 & 65 \\
\hline & & husk & 0.27 & 12.37 & 26,026 & 19 & 494 & 39 \\
\hline Cassava & 490,000 & stalk & 0.06 & 15 & 24,990 & 17.5 & 437 & 37 \\
\hline Other root and tuber crops & 64,500 & stalk & 0.06 & 15 & 3,290 & 17.5 & 58 & 5 \\
\hline \multirow{2}{*}{ Groundnut } & \multirow{2}{*}{4,800} & shells & 0.48 & 8.2 & 2,115 & 16 & 34 & 3 \\
\hline & & straw & 2.30 & 12 & 9,715 & 18 & 175 & 15 \\
\hline \multirow{2}{*}{ Maize } & \multirow{2}{*}{15,000} & stalk & 1.00 & 15.5 & 12,675 & 15 & 190 & 19 \\
\hline & & cob & 0.25 & 8 & 3,450 & 15 & 52 & 5 \\
\hline Total & 684,300 & & & & 125,469 & & 2,131 & 188 \\
\hline
\end{tabular}

Source: FAOSTAT 2005; Koopmans and Koppejan 1997; other root and tuber crops include sweet potatoes, coco yams, and yams; $\mathrm{GWh}$ calculation assumes that a tonne of dry biomass generates on average $1.5 \mathrm{MWh}_{\mathrm{e}}$ with the efficiency in the range of $20-40 \%$.

Table 2. Food Crop Residues in Liberia by County

\begin{tabular}{|l|r|r|r|r|r|r|}
\hline \multirow{3}{*}{ County } & \multicolumn{6}{|c|}{ Annual production (tonnes) } \\
\cline { 2 - 8 } & $\begin{array}{c}\text { Rice Straw } \\
\text { \& Husk }\end{array}$ & Cassava Stalk & $\begin{array}{c}\text { Other Roots \& } \\
\text { Tubers Stalk }\end{array}$ & $\begin{array}{c}\text { Groundnuts } \\
\text { Shell \& Straw }\end{array}$ & $\begin{array}{c}\text { Maize Stalk } \\
\text { \& Cob }\end{array}$ & Total \\
\hline Bomi & 521 & 216 & 19 & 77 & 88 & 921 \\
\hline Bong & 11,128 & 2,360 & 586 & 4,572 & 3,080 & 21,727 \\
\hline Grand Bassa & 3,790 & 1,655 & 34 & 0 & 0 & 5,479 \\
\hline Grand Cape Mount & 812 & 231 & 38 & 0 & 20 & 1,100 \\
\hline Grand Gedeh & 3,589 & 407 & 32 & 0 & 247 & 4,274 \\
\hline Grand Kru & 809 & 244 & 27 & 0 & 0 & 1,080 \\
\hline Lofa & 10,021 & 540 & 173 & 953 & 946 & 12,633 \\
\hline Margibi & 2,667 & 1,922 & 22 & 0 & 1,243 & 5,854 \\
\hline Maryland & 3,686 & 1,170 & 136 & 0 & 894 & 5,885 \\
\hline Montserrado & 5,810 & 9,840 & 792 & 0 & 7,447 & 23,890 \\
\hline Nimba & 16,852 & 4,947 & 1,264 & 5,713 & 1,620 & 30,396 \\
\hline River Cess & 967 & 267 & 16 & 104 & 15 & 1,369 \\
\hline Sinoe & 2,335 & 610 & 107 & 0 & 361 & 3,413 \\
\hline River Gee & 2,387 & 125 & 7 & 0 & 62 & 2,581 \\
\hline Gbarpolu & 3,825 & 458 & 38 & 417 & 177 & 4,915 \\
\hline
\end{tabular}

Unlike other regions in the world, such as Southeast Asia, where food crops are produced commercially and generate large concentrations of residues, much of Liberia's production is run by small households for self-consumption or local markets. Additionally, food crops cultivation in the country is widely scattered. Figure 1 illustrates the food crop residues by county and the

\footnotetext{
${ }^{1}$ The amount of energy produced from biomass depends on the energy conversion technology employed and the scale of operation. However, in general terms for electricity generation, each tonne of dry biomass can generate between 1 and $2 \mathrm{MWh}_{\mathrm{e}}$ with efficiency in the range of $20-40 \%$. This study uses an average conversion of 1.5 MWh per tonne of dry biomass.
} 
location of populated places as an indicator of where these residues are generated within a county. The lack of large-scale food crops production, and their dispersion, increases collection and transportation costs, which would restrain the use of these residues for centralized electricity generation. Moreover, many crop residues and byproducts are seasonal and become available all at once at the same time of the year. Therefore, treatment and storage facilities will be required if they are to be made available as a bio-power feedstock throughout the year.

\section{Caveats}

It is difficult to estimate the amount of food crop residues that is actually available in Liberia for power generation or alternative transportation fuels. Considering Liberian households' lifestyle, it is very likely that a significant portion of the residues identified here are already in use as animal feed, on farm applications, or for cooking and water heating. These resources are site specific and require detailed analyses for any proposed project.

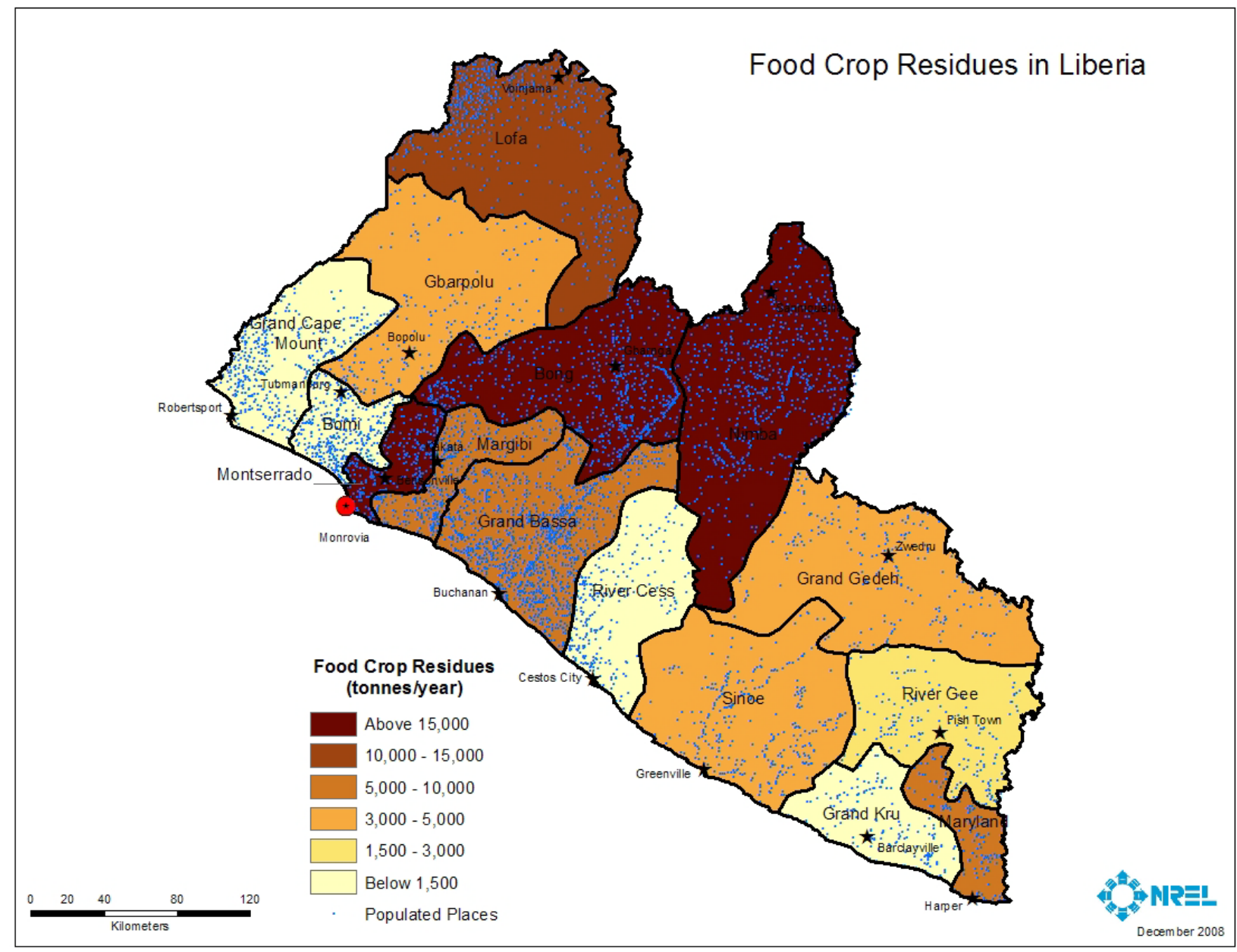

Figure 1. Food Crop Residues in Liberia by County

\section{Cash Crop Residues}

Cash crops grown in Liberia include rubber, coffee, cacao, coconut, sugarcane, plantain/banana (also serving as food crops), oil palm, pineapple, and kola nut (Table 3). Rubber, cacao, and coffee make very important contributions to the Liberian economy, accounting for $22 \%$ of GDP 
in 2005. In addition, these crops are a significant element of export earnings. Rubber currently accounts for almost $90 \%$ of total exports because timber exports, which made up $50-60 \%$ of the total exports until the early 2000s, have been eliminated due to sanctions (MOA 2007). These sanctions were lifted in 2006.

Currently, cash crops in Liberia are grown predominately on small household farms, except rubber and oil palm, grown on a range of small-, medium-, and large-scale production systems. Opportunities for growing cash crops on mid-size, commercial farms exist and it is expected that the share of this production system will grow as the agricultural sector in Liberia revives itself.

Rubber has been Liberia's principle cash crop since the 1920s. The country ranks third in Africa's production of natural latex after Nigeria and Ivory Coast, with about 117,000 tonnes in 2005 (FAOSTAT). Below is a list of the large-scale rubber plantations established in Liberia over the years and Figure 2 illustrates their locations:

- Firestone near Harbel, Margibi County

- Liberia Agricultural Company (LAC) near Buchanan, Grand Bassa County

- Guthrie (also known as Goodrich plantation) near Baha, Bomi County

- Liberia Company (LIBCO) near Cocopa, Nimba County

- Salala Rubber Corporation near Nienka, Margibi County

- Cavalla (initially part of the Firestone concession) near Harper, Maryland County

- Sinoe Rubber Corporation (SRC) near Greenville, Sinoe County

Some of these plantations were abandoned or taken over by rebel forces during the civil war. As a result, many suffered years of poor or indifferent management and would need significant investment to put them back in production. During this time, few plantations changed hands, such as Firestone, which sold its interests to the Japanese-owned Bridgestone in 1988, or ceased operation (the government suspended the agreement with LIBCO in December 2007, citing poor management). The two largest plantations, Firestone and LAC, remained in good condition after the war, and are currently producing significant quantities of rubber. As of July 2007, the Firestone factory was producing 3,000-4,000 tonnes of rubber per month, while LAC was producing about 2,000 tonnes per month (PAC 2007). Two other plantations, Guthrie and Cavalla, reported production of about 4,000 tonnes each in 2006 (MOA 2007). Because of these companies' operation, many household farmers in Liberia note that rubber is their current most important cash crop. They sell raw rubber to the companies, making the industry a big employment generator as well as a major income earner for the country (FAO 2006). 


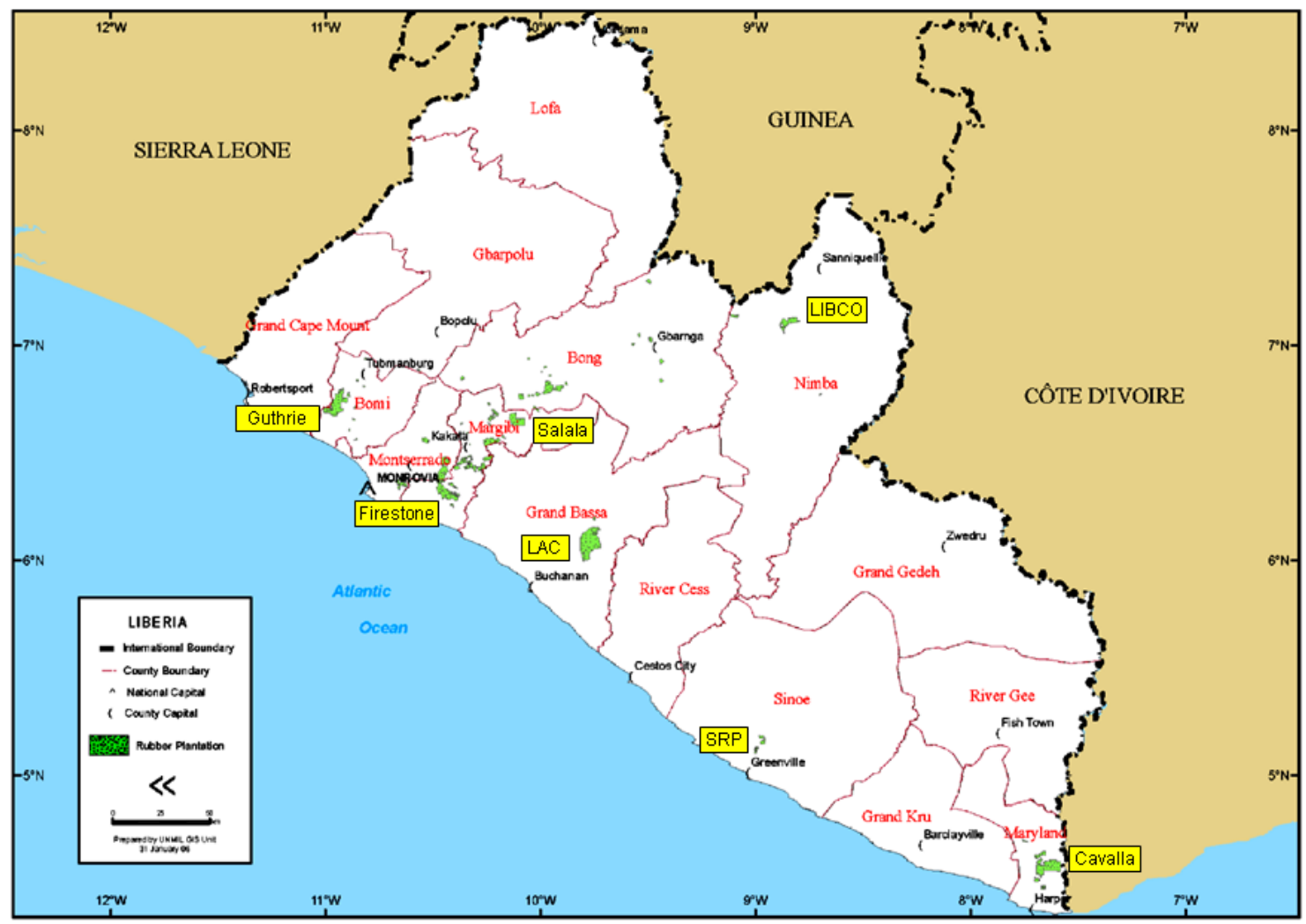

Source: UN 2006

Figure 2. Rubber Plantations in Liberia

The study estimates that large-scale rubber plantations in Liberia today cover an area of approximately 58,000 hectares (Appendix B). This type of plantation generates considerable amounts of wood residues from pruning and replanting activities. According to MOA, the tree stock in these plantations is still productive; however, UNEP indicates they are nearing the end of their productive lifespan. The rotation period, when the trees are cut down for replanting, is 25-30 years. Tree trunks and branches become available during replanting and approximately 81 dry tonnes of wood could be obtained per hectare (about $180 \mathrm{~m}^{3}$ of green wood). Tree trunks are usually used as timber and the small branches ( $54 \%$ of total biomass) are left in the field. If only $10 \%$ of the current rubber tree stock (about 5,800 ha) is replanted, it would result in roughly 254,000 dry tonnes of wood branches. The corresponding energy content is about 4,600 TJ, equivalent to $381 \mathrm{GWh}$ of electricity. Additional biomass resources from rubber trees that could be tapped as an energy source are the leaves. Rubber trees are deciduous - they shed their leaves during the dry season, resulting in a residue resource of about 1.4 tonnes per hectare. The leaves are often disposed of by burning at the end of the dry period. However, if collected, it would result in approximately 69,000 dry tonnes of biomass. Some of the leaves should be left on the field to maintain soil quality and control erosion; however, even if only $30 \%$ of this biomass resource is collected ( 21,000 dry tonnes), about $31.5 \mathrm{GWh}$ of electricity would be generated.

This analysis doesn't evaluate the residues generated from rubber trees grown on household farms because it is assumed that these residues are already in use as firewood or on farm applications. Additionally, MOA reports that more than $75 \%$ of the smallholder farms are newly planted, therefore no significant residue generation is expected in the next 15-20 years. 
Another cash crop grown in Liberia is the cacao tree, whose seeds are the source of cocoa, cocoa butter, and chocolate. The Food and Agriculture Organization (FAO) estimates about 3,000 tonnes of cacao beans are produced annually in Liberia. Cacao trees need shade and are not very suitable for large-scale monoculture plantations, making intercropping with other cash or food crops a common practice in the small household farms. There were, however, a few industrial-scale plantations operated by the Liberia Coffee and Cocoa Corporation (LCCC) in the 1970 s, one in Lofa County (15,000 ha) and another in Nimba County (13,000 ha). As with other industries, these plantations are currently under rehabilitation. Cacao is most commonly grown in interior counties with slightly higher altitudes, such as Grand Gedeh, River Gee, Lofa, and Gbarpolu.

Cacao trees of the unimproved variety become viable after six years and have a productive lifespan of 20-25 years, during which they have to be pruned regularly. Prunings are either left in the field or used as firewood by households. Pruning activities in Liberia would yield about 5,340 dry tonnes of biomass per year with a corresponding energy content of $96 \mathrm{TJ} /$ year (8 GWh). Additionally, replacing old, non-productive trees after 20-25 years results in about $48 \mathrm{~kg}$ of dry organic matter per tree (about $5,760 \mathrm{~kg}$ per hectare), assuming there are 1,200 trees per hectare (Koopmans and Koppejan 1997). The FAO estimates that there are about 17,000 ha currently planted with cacao. According to MOA, the vast majority of cacao trees in Liberia are more than 20 years old. If only $10 \%$ of the current cacao tree stock $(1,700$ ha) is replanted over the next year, it would generate about 10,000 dry tonnes of biomass, equivalent to $176 \mathrm{TJ}$ (15 GWh). Some of this resource is already in use as cacao trees are being cut and burned as charcoal in some areas of Liberia. Besides wood, residues in the form of cacao pods are generated and it is estimated that about 5,220 dry tonnes of pods were produced in 2005. A portion of this material should be left on the field as a source of valuable potassium fertilizer; however, if only $30 \%$ of this biomass resource is collected (1,566 dry tonnes), about $2.3 \mathrm{GWh}$ of electricity would be generated.

Coffee is another cash crop grown in Liberia with about 3,200 tonnes of green coffee produced each year. Coffee dominates in the central and northern counties, particularly in Lofa County, where about $82 \%$ of the farming families are growing the crop (UN 2006).

The coffee tree grows fruit after 3-5 years, for about 50-60 years. Farmers prune coffee trees once per year, in a sequential rotation pattern (it takes 18 or more months for the coffee plants to grow back). The pruned material is left on the field to act as organic fertilizer and provide soil protection. No information is available on the amount of residues generated during coffee pruning activities; therefore, this biomass resource is not considered in this study.

The two main coffee processing by-products are husk and pulp. Coffee husk is produced by processing harvested coffee through the dry method; coffee pulp is produced by the wet method. ${ }^{2}$ Liberia grows mainly Robusta, usually processed by the dry method, making coffee husks available after processing. Some of the husk is used as organic fertilizer, but if compressed into pellets, it can be used for power generation. The study estimates that about 500 dry tonnes of husk are generated per year, with a corresponding energy content of $8 \mathrm{TJ}$ and electricity generation potential of less than one GWh.

Banana and plantains are major products in Liberia, serving as both cash and food crops. They are very important to food security during the hunger season (the period of time when all

\footnotetext{
${ }^{2}$ In the wet method, after harvesting and cleaning, the pulp is removed from the cherry before the drying stage. In the dry method, the entire cherry is placed in the sun to dry.
} 
the food from the previous harvest has been consumed, and the next harvest hasn't begun) because they produce fruit year-round. Bananas and plantains are cultivated by small-scale farmers in every county for household consumption and market supply. Annual production is about 110,000 tonnes for bananas and 42,000 tonnes for plantains.

The life span of individual plants is about 1-1.5 years. Where plants receive care, the mat's lifespan is virtually unlimited because it continually regenerates new plants. Stems and leaves are available as part of the plantations' maintenance activities and it is estimated that about 89 dry tonnes of biomass could be collected per hectare per year (Sheikh 1989). There are about 29,000 ha under banana and plantain cultivation in Liberia; therefore, about 2.6 million tonnes of residues are collected annually. This amount corresponds to 41,000 TJ/year, equivalent to $3,872 \mathrm{GWh}$. Banana and plantain residues have many competing uses, so it is difficult to estimate the amount that could be available for power generation. The stems and leaves are a source of mulch and fertilizer (upon composting), animal fodder, wrapping, eating utensils, and roofing. They are also a source of fiber and can be processed into textiles or used for papermaking. Banana and plantain peels are another type of residue, used as animal feed or left to decompose on the field. They can also be used to produce briquettes or biogas for cooking, heating, and electricity production. The study estimates that about 32,000 dry tonnes of peels are generated annually in Liberia, equivalent to $549 \mathrm{TJ} / y e a r$ or $48 \mathrm{GWh}$.

Oil palm grows throughout Liberia but is particularly abundant in the coastal areas. It can yield cooking oil, animal food, and raw material for the manufacture of cosmetics, detergents, and pharmaceuticals. Palm oil can be used to produce biodiesel or used directly to run low-rpm diesel generators. In addition, the palm residues can be a feedstock for heat and power generation.

Oil palm is different from the other tree crops in that a large part of the final product (palm oil) is obtained from wild groves. FAO estimates that about 35,000 tonnes of palm oil was produced in Liberia in 2007, with perhaps half of that production coming from wild trees. Cultivation is done on small household farms and medium- to large-scale state-owned plantations. Small-scale farms growing oil palm are dominant in Cape Mount County (49\% of all farming families), Gbarpolu (19\%), Nimba (19\%), Sinoe (17\%), and Bomi (17\%). The state-owned plantations were largely abandoned during the war, some partly taken over by the local population for its own use. There has been no maintenance or replanting for about 20 years and the trees are at the end of their productive life. Moreover, all processing facilities were destroyed. A number of these plantations are available for rehabilitation and privatization, covering an area of about 30,000 hectares. Recently, the government granted a management contract to Equatorial Biofuels PIc (EBF), a United Kingdom public company, for Butaw and LIBINCO oil palm plantations. No additional contracts have been awarded and the remaining plantations lie largely abandoned. Figure 3 illustrates the location of oil palm plantations in Liberia and their planted areas. 


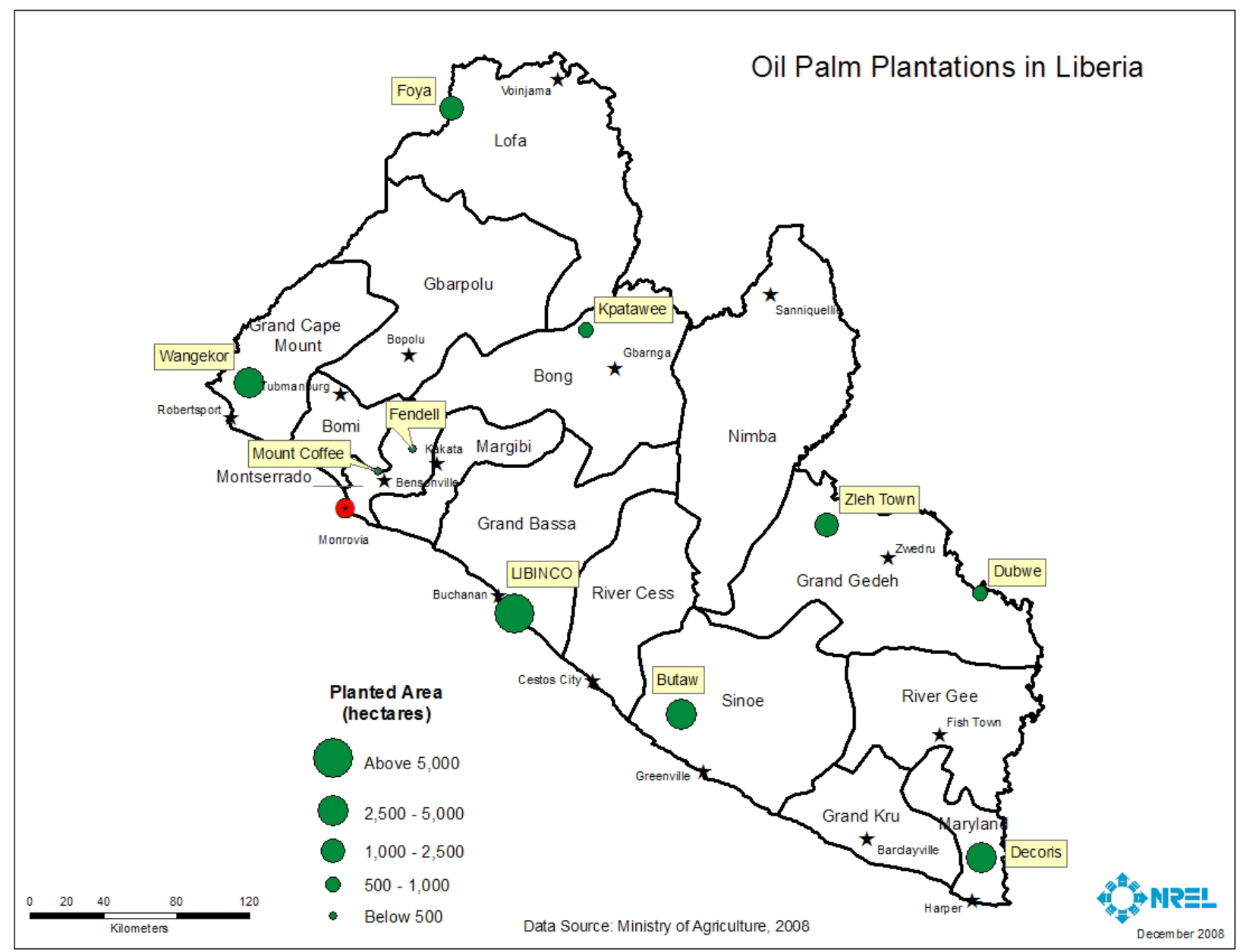

Figure 3. Oil Palm Plantations in Liberia

Oil palm residues generated during processing include fiber, shells, and empty fruit bunches (EFB). Liberia produced 183,000 tonnes of fruits in 2005 and the estimated residues amount to about 104,000 dry tonnes, or 1,680 TJ. Fronds become available on a regular basis during harvesting, and the study estimates that about 247,000 dry tonnes were generated in 2005 $(1,980 \mathrm{TJ})$. All of these residues can be used for power generation and the study estimates that their potential is about $528 \mathrm{GWh}$ (Table 3). However, there are other uses for these residues. For example, EFB are rich in potassium so they are used as fertilizer and the fronds are used for mulching. The productive life of the oil palm tree is about 25-30 years, and during replanting tree trunks and fronds become available. As mentioned earlier, trees on the state-owned plantations are at the end of their productive life, therefore a significant amount of residues could be available in the next few years as part of the rehabilitation process. The average yield per hectare is about 80 dry tonnes of biomass. If only $10 \%$ of the area planted with oil palm trees in Liberia (about 3,000 ha) is replanted, it would yield 240,000 tonnes of biomass, equivalent to $4,320 \mathrm{TJ}$ (360 GWh).

Sugarcane grows very well in Liberia and production in 2005 was estimated at 255,000 tonnes. It is cultivated by small household farms mainly in the coastal south and central countiesMaryland, Nimba, Grand Kru, and Grand Bassa. There is a sugarcane plantation (about 2,428 hectares) with a factory in Maryland County, owned by the Liberia Sugar Corporation 
(LIBSUCO), which was destroyed during the Liberian civil conflict like many other industries in the country. A small quantity of sugar is produced for local consumption and the molasses and syrup are sold locally. In addition to sugar and syrup, alcohol for beverage and medicinal purposes is also produced for domestic and export consumption. The cane-juice liquor ("gin") is traded across the border to the Ivory Coast and is an important source of income.

The sugarcane residues - tops and leaves available during harvesting and the bagasse remaining after crushing - can be used to provide heat and power. These residues are currently used as animal feed, fertilizer (tops and leaves), and for cooking by households. The study estimates that about 76,000 tonnes of sugarcane residues were generated in Liberia in 2005, equivalent to $1,300 \mathrm{TJ}$ or $114 \mathrm{GWh}$ (Table 3).

Coconut in Liberia is grown on small- to mid-size household farms, mainly along the coastline. The only large coconut plantation ( 8,000 ha) is owned by the Liberia Palm and Produce Corporation (LPPC) in Greenville, Sinoe County. It was operated in the 1980s and is currently under rehabilitation. The coconut tree is a source of edible oil and many other products: copra meal provides a highly nutritional animal feed; roots are used in traditional medicine; trunks provide timber; leaves are used as material for roofing, fences, and baskets; waste coconut husks provide fiber and peat; and coconut shells are used to create household products and fashion accessories. The lignocellulosic biomass from coconut trees (trunks, fronds, husks, and shells) are also used as direct fuel for cooking and can be used to provide electricity. The husks themselves can be a good source of charcoal. In addition, the oil can be used to produce biodiesel or used directly to run low-rpm diesel generators.

A study by the Sustainable Rural Enterprise (SRE) estimates that there are more than 81,000 hectares planted with coconut trees in Liberia (Manapol 2007). The average production per hectare per year of a coconut plantation is one tonne, thus about 81,000 tonnes of coconuts are produced annually in Liberia. Applying the appropriate crop to residue ratios, it is estimated that about 80,000 tonnes of processing residues (husks and shells) and 194,000 tonnes of harvesting residues (fronds) are generated. If only $10 \%$ of the area planted with coconut trees in Liberia is replanted, it would yield 7,800 tonnes of biomass equivalent to $125 \mathrm{TJ}$ (12 GWh) (Table 3).

Other cash crops include pineapple and kola nut, grown in every county, and are usually intercropped with other plants. Leading counties for pineapple include Bomi and Grand Bassa, where $29 \%$ of all households are growing the plant, and Cape Mount (21\% of all households). Kola nut is grown in Bomi (28\% of all households), Gbarpolu (17\% of all households), and Montserrado (16\% of all households) (UN 2006).

Annual production of pineapple is estimated at 7,200 tonnes (FAOSTAT). Plants bear for 3-5 years after which they are usually replanted. Up to 80 tonnes of leaves per hectare are available annually after harvesting the fruits (moisture content is very high, $80-85 \%$ ). There are about 1,200 hectares planted with pineapple in Liberia (FAOSTAT), so 19,200 tonnes of dry biomass can be collected annually (265 TJ). The leaves are used as animal feed and are a source of fiber. In some cases they are left on the field. No information is available on the amount of residues generated during harvesting, processing, and replanting of kola tree; therefore, this crop is not considered in the study.

Table 3 summarizes cash crop residues generated annually in Liberia and their relative energy content. The total amount is estimated at 3.9 million tonnes of biomass, equivalent to about 63,000 TJ per year $(5,890 \mathrm{GWh}$ of electricity). Residues from banana and plantains have the 
largest contribution (67\%), followed by biomass material from oil palm (15\%), and rubber (8\%). The distribution of these resources by county is illustrated in Table 4 and Figure 3 . Counties generating the largest amount of residues include Nimba, Montserrado, Margibi, and Bong.

Table 3. Cash Crop Residues in Liberia

\begin{tabular}{|c|c|c|c|c|c|c|c|c|}
\hline Commodity & $\begin{array}{c}\text { Production } \\
\text { (tonnes) }\end{array}$ & Residue Type & $\begin{array}{c}\text { Crop to Residue } \\
\text { Ratio }\end{array}$ & $\begin{array}{c}\text { Moisture } \\
\text { Content (\%) }\end{array}$ & $\begin{array}{c}\text { Residue } \\
\text { (dry tonnes) }\end{array}$ & $\begin{array}{c}\text { LHV } \\
\text { (MJ/kg) }\end{array}$ & $\begin{array}{c}\text { Total } \\
\text { Energy } \\
(\mathrm{TJ} / \mathrm{yr})\end{array}$ & GWh \\
\hline Coffee (green) & 3,200 & husk & 0.18 & 13 & 501 & 17 & 8.52 & 0.75 \\
\hline \multirow{3}{*}{ Cacao (beans) } & 3,000 & pods & 2 & 13 & 5,220 & 18 & 94 & 7.83 \\
\hline & & prunings & 2 & 11 & 5,340 & 18 & 96 & 8.01 \\
\hline & $17,000 \mathrm{ha}$ & wood (replanting) ${ }^{* \star}$ & 5.76 dry tonnes/ha & $\mathrm{N} / \mathrm{A}$ & 9,792 & 18 & 176 & 14.69 \\
\hline \multirow{5}{*}{ Oil Palm (fruit) } & 183,000 & empty fruit bunches & 0.43 & 9 & 71,757 & 16 & 1,148 & 107.64 \\
\hline & & fibre & 0.15 & 10 & 24,705 & 16 & 395 & 37.06 \\
\hline & & kernel shells & 0.05 & 13 & 7,961 & 17 & 135 & 11.94 \\
\hline & & fronds & 2.6 & 48 & 247,416 & 8 & 1,979 & 371.12 \\
\hline & $30,000 \mathrm{ha}^{*}$ & wood (replanting) ${ }^{* \star}$ & 80 dry tonnes/ha & $\mathrm{N} / \mathrm{A}$ & 240,000 & 18 & 4,320 & 360.00 \\
\hline \multirow{4}{*}{ Coconuts } & 81,000 & husk & 0.42 & 10 & 30,618 & 19 & 582 & 45.93 \\
\hline & & shells & 0.7 & 13 & 49,329 & 18 & 888 & 73.99 \\
\hline & & fronds & 2.4 dry tonnes/ha/yr & $\mathrm{N} / \mathrm{A}$ & 194,400 & 18 & 3,499 & 291.60 \\
\hline & $81,000 \mathrm{ha}^{*}$ & wood (replanting) ${ }^{\star \star}$ & 0.96 tonnes/ha & 11 & 7,776 & 18 & 125 & 11.66 \\
\hline \multirow{2}{*}{ Bananas and plantains } & 152,000 & peels & 0.25 & 15 & 32,300 & 17 & 549 & 48.45 \\
\hline & 29,000 ha & stems/leaves & 89 dry tonnes/ha/yr & $\mathrm{N} / \mathrm{A}$ & $2,581,000$ & 16 & 41,296 & $3,871.50$ \\
\hline \multirow{2}{*}{ Rubber } & $58,000 \mathrm{ha}^{*}$ & branches (replanting) ${ }^{\star \star}$ & 44 dry tonnes/ha & $\mathrm{N} / \mathrm{A}$ & 254,000 & 18 & 4,572 & 381.00 \\
\hline & & leaves & 1.4 tonnes/ha & 15 & 68,663 & 18 & 1,236 & 102.99 \\
\hline \multirow{2}{*}{ Sugarcane } & 255,000 & bagasse & 0.29 & 49 & 37,715 & 18 & 679 & 56.57 \\
\hline & & tops/leaves & 0.3 & 50 & 38,250 & 16 & 612 & 57.38 \\
\hline Pineapple & 1,200ha & leaves & 80 tonnes/ha/yr & 80 & 19,200 & 14 & 265 & 28.80 \\
\hline Total & & & & & $3,925,943$ & & 62,655 & 5,889 \\
\hline
\end{tabular}

Source: FAOSTAT (production in 2005); Koopmans and Koppejan 1997; Sajjakulnukit, B., et al 2005; SRE 2007

N/A - Not applicable

* Includes large-scale plantations only;

** Residues are calculated for $10 \%$ of current cacao, rubber, coconut, and oil palm tree stock; GWh calculation assumes that a tonne of dry biomass generates on average $1.5 \mathrm{MWh}_{\mathrm{e}}$ with the efficiency in the range of $20-40 \%$.

Table 4. Cash Crop Residues in Liberia by County

\begin{tabular}{|l|r|r|r|r|r|r|r|r|}
\hline \multirow{3}{*}{ County } & \multicolumn{7}{|c|}{ Annual production (tonnes) } \\
\cline { 2 - 10 } & $\begin{array}{c}\text { Cacao Pods } \\
\text { \& Prunings }\end{array}$ & $\begin{array}{c}\text { Coffee } \\
\text { Husks }\end{array}$ & $\begin{array}{c}\text { Oil Palm } \\
\text { EFB, Fiber, } \\
\text { Shells \& } \\
\text { Fronds }\end{array}$ & $\begin{array}{c}\text { Coconut } \\
\text { Husks \& } \\
\text { Shells }\end{array}$ & $\begin{array}{c}\text { Banana \& } \\
\text { Plantain } \\
\text { Peels }\end{array}$ & $\begin{array}{c}\text { Sugarcane } \\
\text { Tops, } \\
\text { Leaves \& } \\
\text { Bagasse }\end{array}$ & $\begin{array}{c}\text { Rubber } \\
\text { Leaves* }\end{array}$ & Total \\
\hline Bomi & 43 & 1 & 3,766 & 179 & 299 & 564 & 11,900 & 16,750 \\
\hline Bong & 1,177 & 33 & 55,704 & 881 & 2,208 & 10,300 & $\mathrm{~N} / \mathrm{A}$ & 70,303 \\
\hline Grand Bassa & 407 & 4 & 13,094 & 4,840 & 2,248 & 6,860 & 16,660 & 44,114 \\
\hline Grand Cape Mount & 99 & 7 & 19,453 & 1,921 & 185 & 0 & $\mathrm{~N} / \mathrm{A}$ & 21,665 \\
\hline Grand Gedeh & 995 & 15 & 4,000 & 538 & 985 & 0 & $\mathrm{~N} / \mathrm{A}$ & 6,531 \\
\hline Grand Kru & 71 & 0 & 1,279 & 825 & 431 & 1,033 & $\mathrm{~N} / \mathrm{A}$ & 3,639 \\
\hline Lofa & 2,001 & 250 & 27,332 & 0 & 850 & 818 & $\mathrm{~N} / \mathrm{A}$ & 31,252 \\
\hline Margibi & 289 & 0 & 29,318 & 7,882 & 1,845 & 4,388 & 32,725 & 76,448 \\
\hline Maryland & 339 & 3 & 5,163 & 3,123 & 1,673 & 6,375 & 4,760 & 21,435 \\
\hline Montserrado & 650 & 32 & 47,049 & 48,063 & 11,950 & 15,493 & $\mathrm{~N} / \mathrm{A}$ & 123,237 \\
\hline Nimba & 2,790 & 110 & 103,711 & 1,467 & 6,366 & 27,779 & $\mathrm{~N} / \mathrm{A}$ & 142,224 \\
\hline River Cess & 78 & 1 & 3,580 & 1,283 & 387 & 313 & $\mathrm{~N} / \mathrm{A}$ & 5,643 \\
\hline Sinoe & 292 & 7 & 12,394 & 4,116 & 1,115 & 873 & 2,618 & 21,414 \\
\hline River Gee & 471 & 3 & 3,155 & 3,224 & 1,047 & 94 & $\mathrm{~N} / \mathrm{A}$ & 7,994 \\
\hline Gbarpolu & 858 & 37 & 22,690 & 1,605 & 712 & 1,073 & $\mathrm{~N} / \mathrm{A}$ & 26,975 \\
\hline
\end{tabular}

* Large-scale plantations only; N/A - Not applicable; these estimates don't include residues from replanting activities, coconut fronds, banana/plantain stems and leaves, and pineapple residues; EFB - Empty Fruit Bunches. 


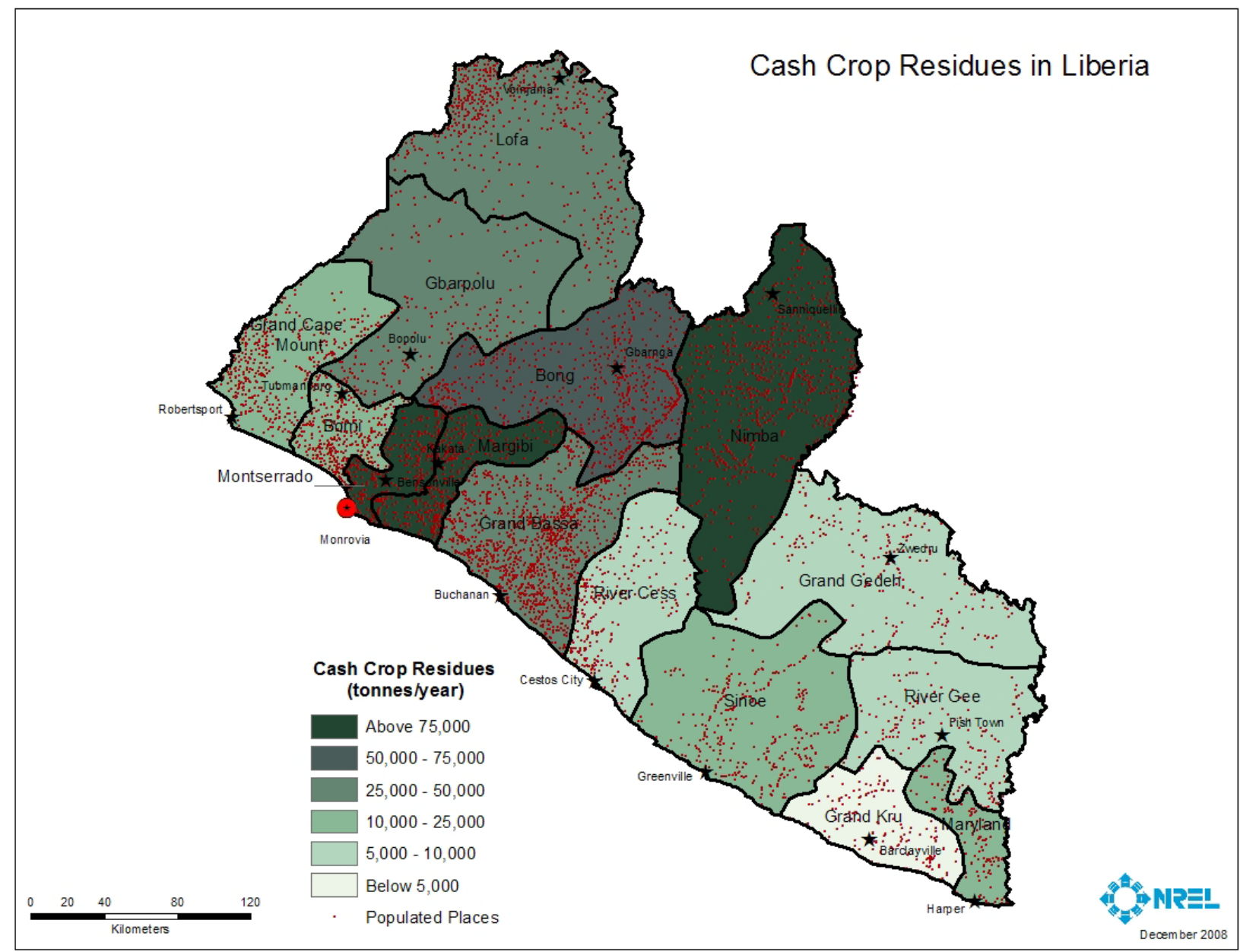

Figure 4. Cash Crop Residues in Liberia by County

\section{Animal Manure}

The livestock sector has never been a major feature of the agriculture in Liberia but it is an important activity to traditional farmers. There are an estimated 2 million hectares of pastureland in the country, yet the livestock sector accounts for only $14 \%$ of agricultural GDP, far below its potential (MOA 2007). According to the United Nations, the main livestock for rural and semiurban Liberians today is poultry (about $47 \%$ of households). About $8 \%$ of farming families own ducks, and $5 \%$ own pigs and goats. Sheep and cattle are hardly present. Before the war, there were seven large cattle farms in Maryland, Grand Kru, and Sinoe counties, covering an area of 2,000 ha. Today they are only slowly being rehabilitated, mainly in Maryland. These three counties are characterized by vast areas of grassland which are less suitable for agricultural production but are ideal for raising livestock (UN 2006).

Livestock manure is used as an organic fertilizer, building material, and energy source. It can be used as fuel in two ways: either burned directly or anaerobically digested to produce biogas ${ }^{3}$, which is then burned. Biogas is a more efficient source of energy than raw manure, and the

\footnotetext{
${ }^{3}$ Biogas is the gaseous product of the anaerobic digestion (decomposition without oxygen) of organic matter. The composition of biogas varies depending upon the origin of the anaerobic digestion process. Typical composition is $\mathrm{CH}_{4}(50 \%$ to $70 \%), \mathrm{CO}_{2}(30 \%$ to $50 \%)$, and traces of gases such as $\mathrm{H}, \mathrm{CO}$, and $\mathrm{N}$.
} 
residue from the bio-digesters (spent slurry) can be used as a valuable fertilizer. Under controlled and optimized conditions, a bio-digester can convert feedstock into biogas in a few days. Small- and medium-scale digesters (up to $6 \mathrm{~m}^{3}$ ) can provide biogas for single-household cooking and lighting in rural communities. Large-scale digesters can supply biogas in large volumes for electricity generation, heat, steam, and transportation fuel production.

The study evaluates the animal manure generation in Liberia and estimates the potential biogas production at about $36 \mathrm{hm}^{3}$ per year, equivalent to $219 \mathrm{GWh}$ (Table 5). An estimate of the biogas potential from animal husbandry on the sub-national level was possible for select counties where data on animal population was available. A project completed by the FAO (Smith 2002) assessed the livestock population in 8 counties: Montserrado, Margibi, Bong, Nimba, Grand Gedeh, Sinoe, River Cess, and Grand Bassa. Among these counties, Nimba had the highest population of livestock in 2001 (more than 21,500 cattle, sheep/goats, pigs, and poultry), followed by Montserrado $(2,180)$, and Grand Gedeh $(1,752)$. Considering the factors outlined in Table 5-animal type, manure generation, and biogas production-Nimba County has the highest potential for electricity generation from biogas $(2,856 \mathrm{MWh})$, followed by Bong (97 MWh), Grand Bassa (80 MWh), Grand Gedeh (59 MWh), Montserrado (42 MWh), Margibi (36 MWh), River Cess (28 MWh), and Sinoe (15 MWh).

Table 5. Animal Manure and Biogas Potential in Liberia

\begin{tabular}{|l|r|r|r|r|r|}
\hline Livestock Type & $\begin{array}{c}\text { Population in 2005 } \\
\text { (heads) }\end{array}$ & $\begin{array}{c}\text { Manure } \\
\text { (kg/head/day) }\end{array}$ & $\begin{array}{c}\text { Biogas Yield } \\
\text { (m3/kg) }\end{array}$ & $\begin{array}{c}\text { Annual Biogas } \\
\text { Production } \\
\text { (hm3) }\end{array}$ & GWh \\
\hline Cattle & 25,000 & 10 & 0.04 & 3.65 & 22 \\
\hline Sheep/goats & 435,000 & 2 & 0.05 & 15.88 & 95 \\
\hline Pigs & 131,000 & 1.5 & 0.07 & 5.02 & 30 \\
\hline Poultry & $5,428,000$ & 0.1 & 0.06 & 11.89 & 71 \\
\hline Total & $6,019,000$ & & & 36.44 & 219 \\
\hline
\end{tabular}

Source: MOA 2007; Manure generation per day considers medium size animals; The calorific value of biogas is about 6 $\mathrm{kWh} / \mathrm{m}^{3}$, which corresponds to about 0.5 liter of diesel oil. The net calorific value depends on the efficiency of the burners or appliances. $\mathrm{hm}^{3}$ - cubic hectometer or $1,000,000 \mathrm{~m}^{3}$

\section{Forest Resources}

\section{Overview of Forestry Sector}

Liberia possesses substantial forest resources covering about 5.7 million hectares, equivalent to $60 \%$ of the total area (FRM 2004). The country is situated in the Upper Guinean Forest, stretching from Cameroon to Guinea, which is believed to shelter a large number of diverse plant and animal species. Liberian forests are characterized by evergreen trees and shrubs along the more humid coastal regions where mangroves are also located; deciduous and mountain species, located in the hills of Northwest Liberia and Mount Nimba; and rainforest in the inland hills and plains. These forests are home to some 250 species of timber, including the highly valued mahoganies and African walnut. Figure 5 illustrates the spatial distribution of forests in Liberia, as well as the 11 designated National Forests in the country (under very limited protection), and the two legally protected areas, Sapo National Park (approximately 149,000 ha) and East Nimba (about 15,000 ha). 


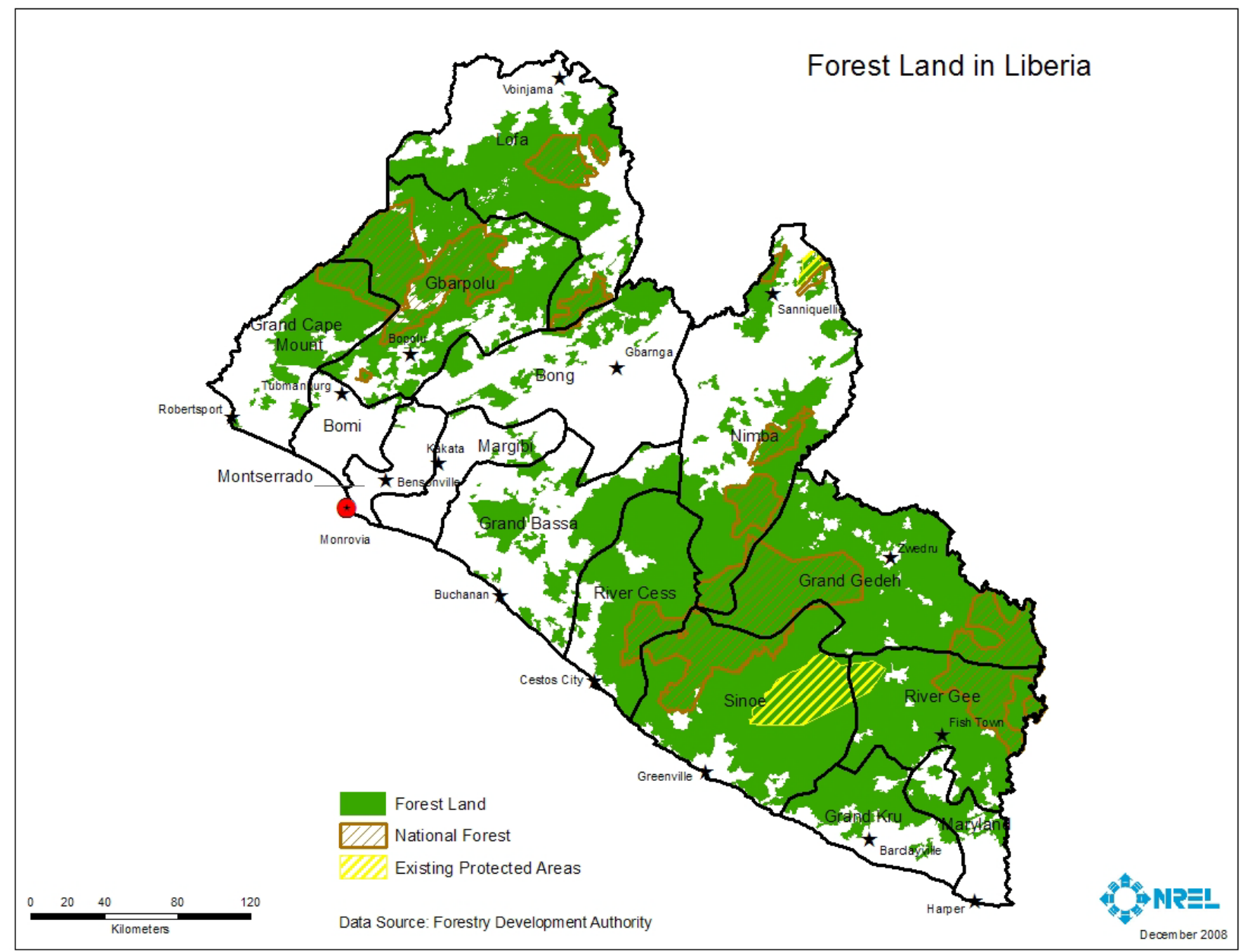

Figure 5. Forest Land in Liberia

Liberia's forests are of special importance to the economy because they provide employment in the rural areas, fuel sources (charcoal and firewood), and export products (logs and timber). However, forest resources were mismanaged and the revenue generated from the sector was misappropriated during Liberia's civil conflict. As a result, the United Nations Security Council imposed sanctions on Liberia's timber exports in 2003 (FDA 2007). In 2004, the Liberian government, assisted by the international community, examined all 70 logging companies in Liberia. In addition to the lack of legality, the concession review found that these companies had violated many environmental, labor, and forestry laws and regulations (Woods et al. 2008). Following the concession review, President Sirleaf's administration cancelled all concessions by executive order in February 2006, put in place a moratorium on all logging activities, and passed a new National Forestry Reform Law. In June 2006, the U.N. Security Council acknowledged the reforms of the new government and lifted the sanctions on timber.

The Forestry Development Authority (FDA) is the sole government agency responsible for managing forest resources in Liberia. As a part of the forestry reform program, the FDA identifies areas suitable for logging and awards the harvesting contracts through competitive bidding. The new agreements are focused on responsible logging, which considers the environment and the needs of local communities. According to the National Forestry Strategy, 
there are two distinct types of logging contracts meant to achieve different objectives (Woods et al 2008):

- Forest Management Contracts (FMC): Long-term contracts for large areas of up to 400,000 hectares (akin to the traditional concessions). Small FMCs (50,000-100,000 hectares) are reserved for majority-owned (51\%) Liberian companies, although they represent an opportunity for joint ventures between domestic and foreign partners. There are no restrictions on company ownership for larger FMCs.

- Timber Sale Contracts (TSC): Short-term contracts (less than 3 years) for smaller areas (less than 5,000 hectares). TSCs are focused on areas that will likely be cleared for plantations or farming, therefore the management requirements for harvesting the timber is less onerous. This means that TSCs require less planning and can be awarded more easily than FMCs. TSCs are also reserved for majority-owned Liberian companies.

Figure 6 illustrates the areas suitable for these two types of logging contracts.

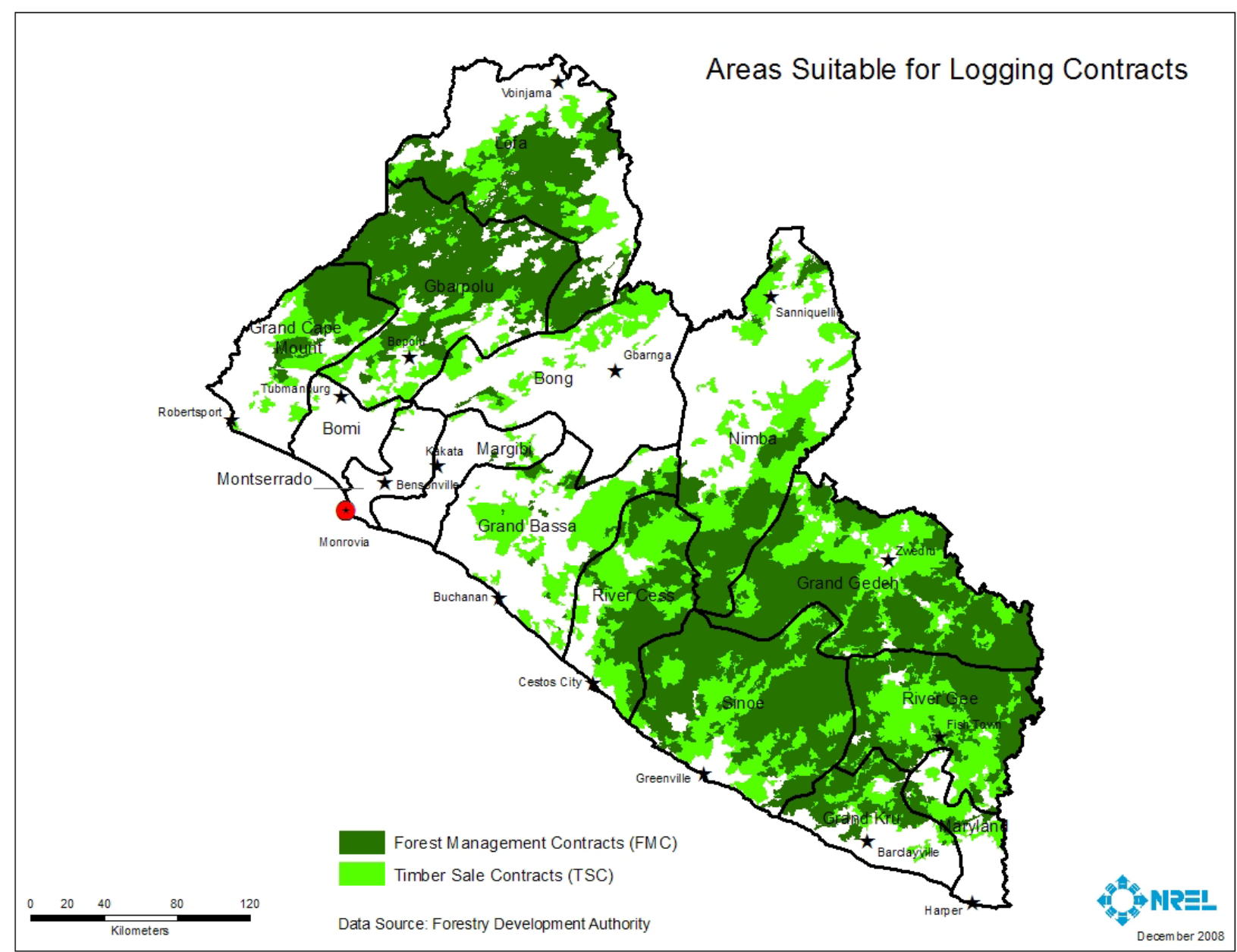

Figure 6. Areas Suitable for Logging Contracts in Liberia

In 2008, through the FDA, the government awarded three FMCs and six TSCs to pre-qualified companies in various counties. Additionally, the FDA announced that four more FMCs were 
available for purchase as of December 5, 2008. Table 6 illustrates the location, ownership, and size of the existing and pending logging contracts in Liberia.

Table 6. Logging Contracts in Liberia

\begin{tabular}{|l|c|l|r|}
\hline \multicolumn{1}{|c|}{ County } & Contract Category & \multicolumn{1}{|c|}{ Ownership } & Area (hectares) \\
\hline Gbarpolu and Lofa & FMC "A" & Alpha Logging and Wood Processing Inc. & 119,240 \\
\hline River Cess & FMC "B" & EJ and J Investment Corporation & 57,262 \\
\hline River Cess & FMC "C" & Liberia Tree and Trade Company & 59,374 \\
\hline Grand Gedeh and River Gee & FMC "F" & Pending & 253,670 \\
\hline Grand Gedeh and Sinoe & FMC "I" & Pending & 131,466 \\
\hline Nimba, Grand Gedeh and River Cess & FMC "K" & Pending & 266,910 \\
\hline Grand Kru, Maryland and River Gee & FMC "P" & Pending & 119,344 \\
\hline & & & 5,000 \\
\hline Grand Bassa & TSC "A2" & Tarpeh Timber Corporation Inc. & 5,000 \\
\hline Grand Bassa & TSC "A3" & Tarpeh Timber Corporation Inc. & 5,000 \\
\hline Bong and Gbarpolu & TSC "A6" & B \& V Timber Company Inc. & 5,000 \\
\hline Gbarpolu & TSC "A7" & Bargor \& Bargor Enterprise Inc. & 5,000 \\
\hline Grand Cape Mount & TSC "A9" & B \&V Timber Company Inc. & 5,000 \\
\hline Grand Cape Mount & TSC "A10" & B \& Vimber Company Inc. & $\mathbf{1 , 0 3 7 , 2 6 6}$ \\
\hline Total & & & \\
\hline
\end{tabular}

Source: FDA 2008

Forest Residues include wood residues from logging and wood-processing activities. Logging residues are the unused portions of trees cut during logging operations and left in the woods. These include stumps, branches, leaves, off-cuts, and sawdust. Wood-processing residues, or primary mill residues, are composed of wood materials (such as discarded logs, bark, sawdust, and shavings) generated at manufacturing plants-sawmill, veneer mill, plywood mill, or pulp mill-when round-wood products are processed into primary wood products. Forest residues can be used to generate heat, electricity, liquid fuels, and solid fuels (compressed wood such as pellets, briquettes, or charcoal briquettes).

As mentioned above, due to the forestry reform program, the government cancelled all concession agreements across Liberia in early 2006. Consequently, there are no formal forestry activities in the country, though small-scale pit sawing is evident in many areas. This study evaluates the forest residues that could potentially be available in the country after logging concessions resume operation. It estimates that about $19.6 \mathrm{hm}^{3}$ of forest residues could be collected, equivalent to 162,645 TJ per year, or 15,248 GWh of electricity (Table 7). The analysis methodology is described below.

Table 7. Forest Residues in Liberia

\begin{tabular}{|l|r|r|r|r|}
\hline Forest Residues & Volume (hm3) & Weight (Mt) & Total energy (TJ/yr) & GWh \\
\hline Logging & 8.71 & 6,898 & 110,373 & 10,347 \\
\hline Saw-milling & 10.89 & 3,267 & 52,272 & 4,901 \\
\hline Total & 19.6 & 10,165 & 162,645 & 15,248 \\
\hline
\end{tabular}

$\mathrm{hm}^{3}$ - cubic hectometer $\left(1 \mathrm{hm}^{3}=1,000,000 \mathrm{~m}^{3}\right)$; Mt - Megatonne $\left(10^{6}\right.$ tonnes); conversion of volume to mass is based on average density of $792 \mathrm{~kg} / \mathrm{m} 3$ for logging residues and $300 \mathrm{~kg} / \mathrm{m} 3$ for saw-milling residues with a moisture content of $20 \%$. GWh calculation assumes that a tonne of dry biomass generates on average $1.5 \mathrm{MWh}_{\mathrm{e}}$ with the efficiency in the range of $20-40 \%$; Air-dry wood ( $20 \%$ moisture content) has an energy value of about $16 \mathrm{MJ} / \mathrm{kg}$.

The current logging contracts in Liberia cover an area of about 1 million hectares (Table 6). According to Mano Properties \& Investment, Inc., a company registered with the FDA and pre- 
qualified for TSCs, the average forest yield in the country is about $21 \mathrm{~m}^{3}$ per hectare (MPI 2008). Therefore, approximately $21.78 \mathrm{hm}^{3}$ of wood could be available from forest lands. Residue generation varies considerably depending on species and local practices. For the purpose of this study, an average recovery factor of $40 \%$ for logging residues and $50 \%$ (38\% solid wood waste and $12 \%$ sawdust) for saw-milling residues was used. This corresponds to roughly $9 \mathrm{hm}^{3}$ of logging residues and $11 \mathrm{hm}^{3}$ of saw-milling residues (Table 7). Table 8 and Figure 7 illustrate the distribution of these resources by county and the analysis methodology is presented in Appendix C.

Table 8. Forest Residues in Liberia by County

\begin{tabular}{|l|r|r|r|r|r|}
\hline \multicolumn{1}{|c|}{ County } & Area (ha) & $\begin{array}{c}\text { Yield } \\
\text { (dam3) }\end{array}$ & $\begin{array}{c}\text { Logging Residues } \\
\text { (dam3) }\end{array}$ & $\begin{array}{c}\text { Saw-milling Residues } \\
\text { (dam3) }\end{array}$ & $\begin{array}{c}\text { Total } \\
\text { (dam3) }\end{array}$ \\
\hline Bomi & 0 & 0 & 0 & 0 & 0 \\
\hline Bong & 2,700 & 57 & 23 & 28 & 51 \\
\hline Grand Bassa & 10,000 & 210 & 84 & 105 & 189 \\
\hline Grand Cape Mount & 10,000 & 210 & 84 & 2,768 & 4,983 \\
\hline Grand Gedeh & 263,643 & 5,537 & 2,215 & 823 & 1,481 \\
\hline Grand Kru & 78,344 & 1,645 & 658 & 626 & 1,127 \\
\hline Lofa & 59,620 & 1,252 & 501 & 0 & 0 \\
\hline Margibi & 0 & 0 & 0 & 168 & 302 \\
\hline Maryland & 16,000 & 336 & 134 & 0 & 0 \\
\hline Montserrado & 0 & 0 & 0 & 1,260 & 2,268 \\
\hline Nimba & 120,000 & 2,520 & 1,008 & 2,054 & 3,698 \\
\hline River Cess & 195,636 & 4,108 & 1,643 & 690 & 1,242 \\
\hline Sinoe & 65,733 & 1,380 & 552 & 1,561 & 2,810 \\
\hline River Gee & 148,670 & 3,122 & 1,249 & 703 & 1,265 \\
\hline Gbarpolu & 66,920 & 1,405 & 562 & & \\
\hline
\end{tabular}




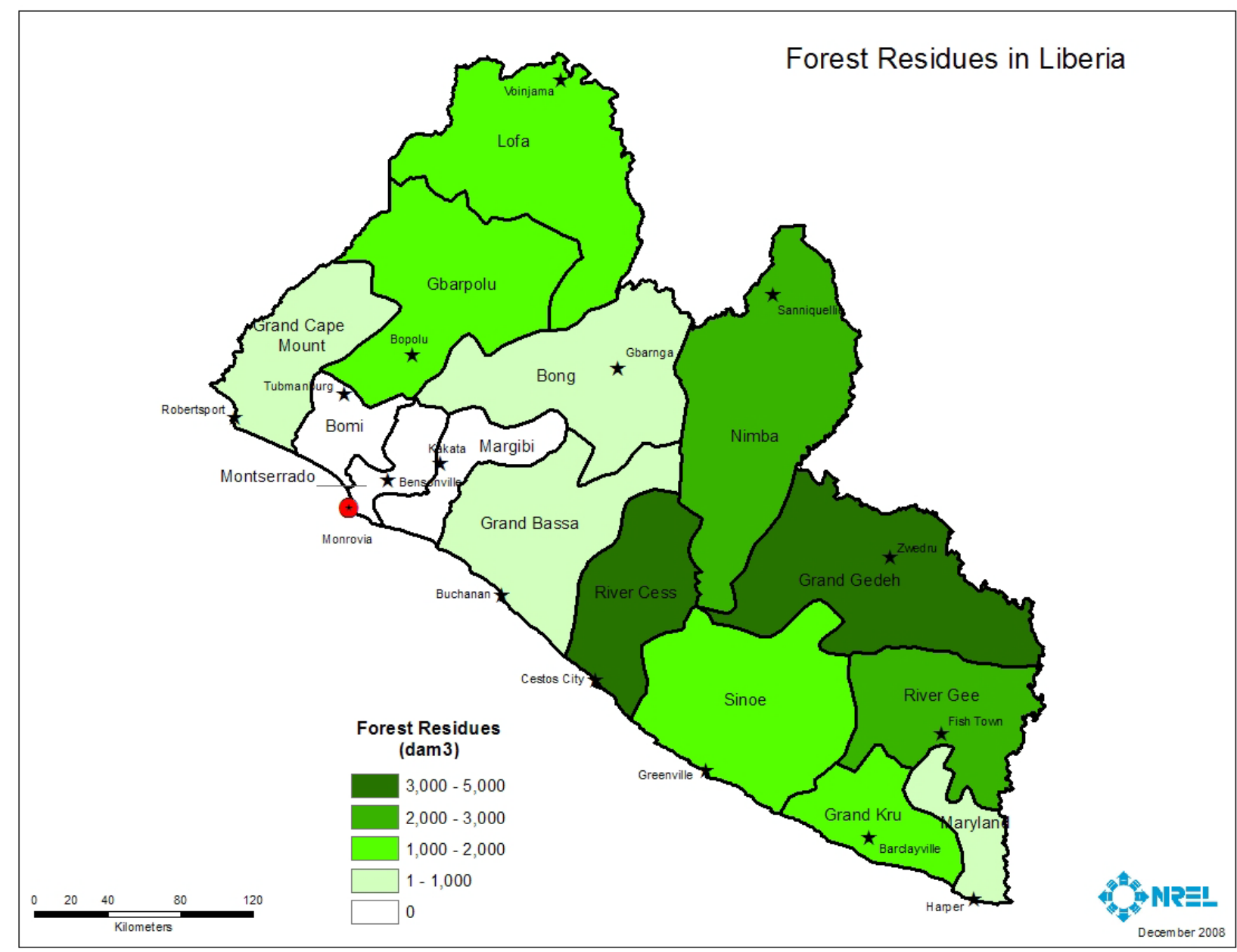

Figure 7. Forest Residues in Liberia by County

\section{Urban Resources}

The concentration of population and activities in urban areas is responsible for the generation of waste. This waste, referred to as municipal solid waste (MSW), is generated by households and the commercial and industrial sectors. The waste takes many forms, including plastics, paper, textiles, glass, metal, wood, food, and other organic wastes. MSW, particularly the biogenic fraction, is a resource that can be converted to electricity, heat, gaseous and liquid fuels through thermo-chemical (incineration, pyrolysis, and gasification), and bio-chemical (anaerobic digestion and fermentation) conversion processes.

The use of waste as an energy source provides two important benefits of environmentally safe waste management and disposal, as well as the generation of clean electric power. Waste-toenergy combustion reduces the volume of trash by about $90 \%$, resulting in a $90 \%$ decrease in the amount of land required for garbage disposal. The amount of ash on a weight basis is as high as $25 \%$ of the input. Using biogas emitted from landfill sites, also called "landfill gas", can capture roughly $60-90 \%$ of the methane, depending on system design and effectiveness. Given that all landfills generate methane, it is logical to use the gas for energy generation rather than emitting this highly potent greenhouse gas to the atmosphere (U.S. EPA). 
The waste disposal method practiced in Liberia is open dumping and swampland reclamation. There is a complete absence of engineered landfills, though one is under development in Wehnn Town, Montserrado County; instead, there are many dumpsites available in proximity to major communities posing threat to humans' health, wetland ecosystems, and water resources. Despite the fact that there are no landfill sites in Liberia, the study evaluates the MSW resource to illustrate its electricity generation potential. Waste-to-energy and landfill gas-to-energy facilities tend to be built at the landfills of large urban centers, although small-scale projects could be developed in rural areas. Therefore, the study estimates the generation potential of waste-to-power in major populated places in Liberia with more than 5,000 people.

Estimations for MSW generated in Liberia's major urban areas use 2008 population numbers derived from the National Population and Housing Census (LISGIS 2008) and a factor that relates population to the amount of post-consumer residue generation. A waste generation rate of $0.6 \mathrm{~kg} /$ day $/$ person was used in this study adopted from the World Bank Technical Paper No. 426 (World Bank 1999), which includes $0.5 \mathrm{~kg} /$ day/person for domestic waste generation, plus a further $0.1 \mathrm{~kg} / \mathrm{day} / \mathrm{cap}$ for commercial and industrial waste. Figure 8 illustrates the results of this analysis.

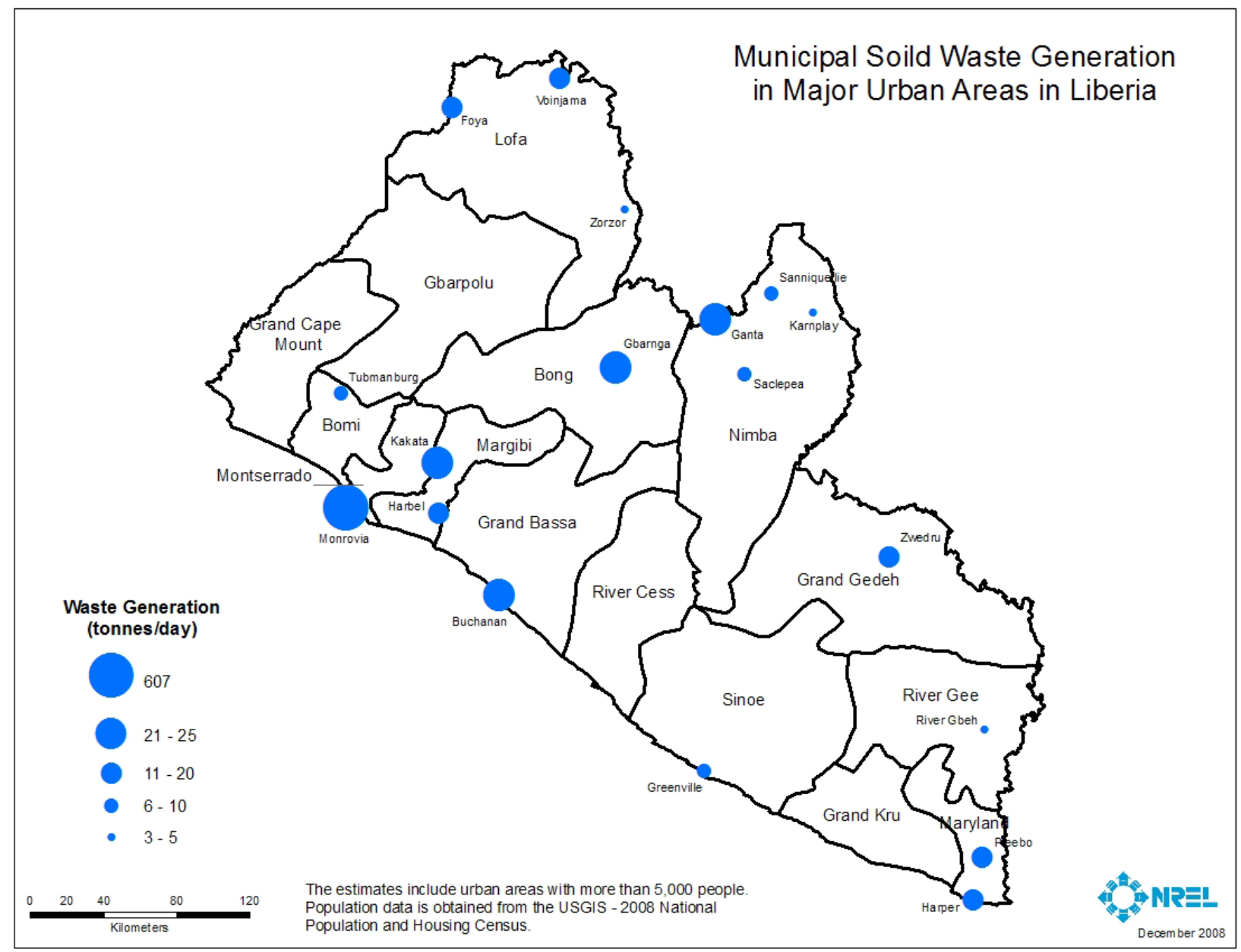

Figure 8. Municipal Solid Waste Generation in Major Urban Areas in Liberia 
The amount of MSW generated annually in Liberia's major urban areas is estimated at 270,000 tonnes (Table 9). The biogenic materials (paper, wood, textiles, and vegetable/putrescibles) are $64 \%$ of total MSW or about 172,000 tonnes, based on the waste composition in Liberia (Table 10). A typical waste-to-energy plant generates about $550 \mathrm{kWh}$ per tonne of waste combusted. Modern waste incineration plants have efficiencies for power generation of $20 \%-25 \%$, and new designs could exceed $30 \%$. The electrical energy from the biogenic portion of the MSW in Liberia's major urban areas, via thermo-chemical conversion, is estimated at $52 \mathrm{GWh}$ per year.

Table 9. Municipal Solid Waste Generation and Electricity Potential in Major Urban Areas in Liberia

\begin{tabular}{|c|c|c|c|c|}
\hline Urban Area & Population & $\begin{array}{l}\text { MSW Generation } \\
\text { (tonnes/yr) }\end{array}$ & $\begin{array}{l}\text { Biogenic MSW } \\
\text { Generation } \\
\text { (dry tonnes/yr) }\end{array}$ & $\begin{array}{l}\text { Electrical Energy via } \\
\text { Thermo-Chemical Pathway } \\
\text { (MWh/yr) }\end{array}$ \\
\hline Saclepea & 12,117 & 2,399 & 834 & 459 \\
\hline Monrovia & $1,010,970$ & 200,172 & 69,580 & 38,269 \\
\hline Tubmanburg & 13,114 & 2,597 & 903 & 496 \\
\hline Foya & 19,522 & 3,865 & 1,344 & 739 \\
\hline Zorzor & 5,131 & 1,016 & 353 & 194 \\
\hline Voinjama & 26,594 & 5,266 & 1,830 & 1,007 \\
\hline Ganta & 41,106 & 8,139 & 2,829 & 1,556 \\
\hline Harper & 17,837 & 3,532 & 1,228 & 675 \\
\hline Karnplay & 7,664 & 1,517 & 527 & 290 \\
\hline Pleebo & 22,963 & 4.547 & 1,580 & 869 \\
\hline River Gbeh & 7.313 & 1.448 & 503 & 277 \\
\hline Sanniquellie & 11,415 & 2,260 & 786 & 432 \\
\hline Zwedru & 23,903 & 4,733 & 1,645 & 905 \\
\hline Buchanan & 34,270 & 6,785 & 2,359 & 1,297 \\
\hline Gbarnga & 34,046 & 6,741 & 2,343 & 1,289 \\
\hline Greenville & 16,434 & 3,254 & 1,131 & 622 \\
\hline Harbel & 23,402 & 4,634 & 1,611 & 886 \\
\hline Kakata & 33,945 & 6,721 & 2,336 & 1,285 \\
\hline Total & $1,361,746$ & 269,626 & 93,722 & 51,547 \\
\hline
\end{tabular}

Population numbers are for 2008; waste generation rate: $0.6 \mathrm{~kg} /$ day/person; the study considers 330 annual operating days; Biogenic materials are $64 \%$ of total MSW with moisture content as follow: paper $-6 \%$, wood $/$ straw $-40 \%$, textiles $-10 \%$, vegetable/putrescibles $-60 \%$; Thermo-Chemical pathway considers incineration technology. 
Table 10. Waste Composition in Monrovia

\begin{tabular}{|l|l|}
\hline Waste composition in Monrovia \\
\hline Component & $\%$ by weight \\
\hline Paper & 10.0 \\
\hline Glass, Ceramics & 1.2 \\
\hline Metals & 2.0 \\
\hline Plastics & 13.0 \\
\hline Leather, Rubber & 0.2 \\
\hline Wood, Bones, Straw & 4.6 \\
\hline Textiles & 6.0 \\
\hline Vegetable /Putrescible & 43.0 \\
\hline Miscellaneous Items & 20.0 \\
\hline Total & 100 \\
\hline Density & $250 \mathrm{~kg} / \mathrm{m3}$ \\
\hline
\end{tabular}

Source: UNEP 2007; adopted from the Waste Management Plan for Monrovia, 2004

Note: Miscellaneous items include sand, ash, and small grained and wet food waste that could not be sorted.

An alternative treatment of the biogenic waste fraction is anaerobic digestion. Approximately 50 to $200 \mathrm{~m}^{3}$ of landfill gas is produced per tonne of MSW collected and dumped in landfills. The volume of gas produced depends on several factors: the amount, type, and age of waste; moisture content; temperature; $\mathrm{pH}$; and site conditions. Without a particular site in mind, it is difficult to estimate the energy potential of MSW via bio-chemical conversion in Liberia. Also, it is difficult to put a timeframe on landfill gas recovery. As opposed to bio-digesters where waste feedstock is converted to biogas in controlled, optimized conditions, anaerobic decomposition in a landfill is uncontrolled and very slow. It may take several years before the level of production is sufficient to fuel an electricity generator, although an advanced technology exists to accelerate the digestion process within a few months.

\section{Potential Biomass Resources}

Real opportunities for biomass resource expansion exist in Liberia considering the favorable agro-climatic conditions. As mentioned earlier, the Liberian soils are better adapted to tree-crop agriculture than annual field-crop production. Even if food-crop production increases, it will predominantly be used to secure food supply rather than as a biomass resource. Therefore, the study evaluates the potential expansion of tree crops in the country, particularly oil palm and coconut. These two crops have diverse applications as an energy source-they can be used in parallel as feedstock for the production of transportation fuels and power generation. Sugarcane is also evaluated for the same reason. The study does not evaluate the potential forest resources in Liberia due to the reforms that are taking place in this sector and the uncertainty of their outcome. Additionally, all of the proposed protected areas fall within the forest lands (see Appendix $\mathrm{C}$ ); therefore, the extent of the areas that are designated as protected would determine the forest land available for logging, and respectively, the residues that could be collected as biomass. The same applies to the rubber, coffee, and cacao industries which are going through a rehabilitation process. 
The study estimates that of the total cropland in Liberia, only $6 \%$ is currently cultivated. The remaining cropland amounts to some 3 million hectares. It is unrealistic to assume that all of this land would go under tree-crop cultivation. A portion of it may go under afforestation to maintain forest ecosystems and their unique biodiversity, or be used for food crops production and other agricultural activities, or be converted to urban land. Therefore, the study evaluates the fuel and power production potential of biomass resources grown on the available cropland under three scenarios: using $10 \%, 25 \%$, and $50 \%$ of the available cropland for cash crop expansion. The results of this analysis are presented in Table 11 and Table 12.

Liberia, situated in the tropical biome, has the advantage of growing the most desirable feedstocks for biofuels production-with the highest yield per land unit-compared to those in the temperate biome. Liberian feedstocks include oil palm, coconut, and sugarcane. Biodiesel yielded from oil palm is about 6,000 L/ha. Rapeseed supplies on average 1,200 L/ha and soybeans about $500 \mathrm{~L} / \mathrm{ha}$. Ethanol yielded from sugarcane is between 5,000-6,500 L/ha while corn supplies about $3,100 \mathrm{~L} / \mathrm{ha}$. If only $10 \%$ of the available cropland is used to expand oil palm or coconut cultivation, it would yield about $1,800 \mathrm{dam}^{3}$ and $641 \mathrm{dam}^{3}$ of biodiesel per year, respectively. If $10 \%$ of the available cropland is used for expansion of sugarcane production, it would yield about $1,500 \mathrm{dam}^{3}$ of ethanol annually. This volume of biofuels would be more than enough to cover the country's transportation needs of about 206 dam $^{3}$ per year (Index Mundi 2005). In addition to vegetable oil, used cooking oil and animal fat could also be used as feedstocks for biodiesel production. Moreover, as one liter of vegetable oil provides about 2 $\mathrm{kWh}$ of electricity with conversion efficiency at $21 \%$, these oils and fats could be used directly in stand-alone diesel generators to provide electricity for rural communities.

As mentioned earlier, the residues generated during the harvesting and processing of the tree and herbaceous crops can be used to generate electricity or to produce charcoal, thereby reducing deforestation and improving public health. In the case of sugarcane, bagasse can be used to provide heat and electricity for use in the mill, making the industrial process selfsufficient and even generating a surplus. If $10 \%$ of the available cropland is used to expand the cultivation of oil palm, coconut, or sugarcane, it would generate about 18,000 GWh, $452 \mathrm{GWh}$, and 9,000 GWh of electricity per year, respectively. This production would be more than enough to meet Liberia's current electricity consumption of 297 GWh (CIA 2005). In addition to power generation, the crop residues could be used to produce transportation fuels via advanced conversion technologies: ethanol production via enzymatic fermentation and Fischer Tropsch hydrocarbons via gasification to syngas (a mixture of carbon monoxide and hydrogen). Significant research and development efforts are underway in many developed countries to improve and commercialize these technologies.

Another multipurpose plant receiving a lot of attention recently is Jatropha Curcas. This tropical perennial shrub is already used as a live fence and to control erosion; the oil extracted from the seeds is used for medicinal purposes and soap making; and the seedcake is used as organic fertilizer and animal feed. As of late, the plant's oil has been targeted as a feedstock for biodiesel production or a direct substitute for petroleum diesel in power generators. In addition, the processing residues (shells and husks) can be used as solid biofuels in power plants. 
Table 11. Biofuels Potential in Liberia

\begin{tabular}{|c|c|c|c|c|c|c|c|c|c|c|c|c|c|c|c|}
\hline \multirow[b]{2}{*}{ County } & \multirow[b]{2}{*}{$\begin{array}{l}\text { Total Area } \\
\text { (ha) }\end{array}$} & \multirow[b]{2}{*}{$\begin{array}{c}\text { Cropland } \\
\text { (ha) }\end{array}$} & \multicolumn{3}{|c|}{ Cropland Under Cultivation (ha) } & \multirow[b]{2}{*}{$\begin{array}{c}\text { Available } \\
\text { Cropland (ha) }\end{array}$} & \multicolumn{3}{|c|}{ Biodiesel from palm oil (dam $3 / y r)$} & \multicolumn{3}{|c|}{ Biodiesel from coconut oil (dam3/yr) } & \multicolumn{3}{|c|}{ Ethanol from sugarcane (dam $3 / y r)$} \\
\hline & & & $\begin{array}{c}\text { Area Planted by } \\
\text { Small Household } \\
\text { Farms }\end{array}$ & $\begin{array}{c}\text { Area Planted by } \\
\text { Large Plantations }\end{array}$ & Total & & $\begin{array}{c}10 \% \text { of } \\
\text { Available } \\
\text { Cropand }\end{array}$ & $\begin{array}{l}25 \% \text { of } \\
\text { Available } \\
\text { Cropland }\end{array}$ & $\begin{array}{c}50 \% \text { of } \\
\text { Available } \\
\text { Cropland }\end{array}$ & $\begin{array}{c}10 \% \text { of } \\
\text { Available } \\
\text { Cropland }\end{array}$ & $\begin{array}{c}25 \% \text { of } \\
\text { Available } \\
\text { Cropland }\end{array}$ & $\begin{array}{c}50 \% \text { of } \\
\text { Available } \\
\text { Cropland }\end{array}$ & $\begin{array}{c}10 \% \text { of } \\
\text { Available } \\
\text { Cropland }\end{array}$ & $\begin{array}{l}25 \% \text { of } \\
\text { Available } \\
\text { Cropland }\end{array}$ & $\begin{array}{c}50 \% \text { of } \\
\text { Available } \\
\text { Cropland }\end{array}$ \\
\hline Bomi & 212,188 & 200,064 & 1,858 & 10,000 & 11,858 & 188,206 & 113 & 282 & 565 & 40 & 99 & 198 & 94 & 235 & 471 \\
\hline Bong & 838,360 & 670,361 & 53,451 & 607 & 54,058 & 616,303 & 370 & 924 & 1,849 & 129 & 324 & 647 & 308 & 770 & 1,541 \\
\hline Grand Bassa & $\begin{array}{l}030,300 \\
747,785 \\
\end{array}$ & 449,696 & 28,989 & 27,759 & 56,748 & $\begin{array}{l}392,948 \\
3929\end{array}$ & 236 & 589 & $\mid 1,179$ & \begin{tabular}{r|r|}
29 \\
83
\end{tabular} & 206 & $\frac{4+13}{413}$ & 2006 & 491 & $\frac{1,544}{982}$ \\
\hline Grand Cape Mount & 496.254 & 189,867 & 5,181 & 2.833 & 8.014 & 181,853 & 109 & 273 & 546 & 38 & 95 & 191 & 91 & 227 & 455 \\
\hline Grand Gedeh & $1,028,201$ & 41,482 & 13,048 & 2,186 & 15,234 & 26,248 & 16 & 39 & 79 & 6 & 14 & 28 & 13 & 33 & 66 \\
\hline Grand Kru & $\frac{1,02,201}{369,909}$ & $\frac{417,4036}{117,036}$ & 2,264 & 0 & 2,264 & $\begin{array}{r}2,240 \\
114,772 \\
\end{array}$ & 69 & $\begin{array}{r}172 \\
172\end{array}$ & 344 & 24 & 60 & 121 & 57 & 143 & 287 \\
\hline Lofa & $1,031,743$ & 440,149 & 68.789 & 17.428 & 86,217 & 353,931 & 212 & 531 & 1,062 & 74 & 186 & 372 & 177 & 442 & 885 \\
\hline Margibi & 281,222 & 239,856 & 29,280 & 27,500 & 56,780 & 183,076 & 110 & 275 & 549 & 38 & 96 & 192 & 92 & 229 & 458 \\
\hline Maryland & \begin{tabular}{|l|l|}
218,819 \\
\end{tabular} & $\begin{array}{l}2117,641 \\
11,0\end{array}$ & $\begin{array}{l}16,843 \\
\end{array}$ & $\mid 10,880$ & 27,723 & $\begin{array}{r}89,917 \\
\end{array}$ & 54 & 135 & 270 & 19 & 47 & 94 & 45 & 112 & 225 \\
\hline Montserrado & 181,113 & 167,077 & 166,652 & 425 & 167,077 & & 0 & 0 & 0 & 0 & 0 & 0 & 0 & 0 & \\
\hline Nimba & $1,191,121$ & 652,135 & $\mid 66,145$ & 13,000 & 79,145 & 572,990 & 344 & 859 & 1,719 & 120 & 301 & 2002 & 286 & 716 & 1,432 \\
\hline River Cess & $\begin{array}{r}, 528,199 \\
\end{array}$ & $\begin{array}{r}76,132 \\
\end{array}$ & | & 0 & 5,840 & 70,291 & 42 & 105 & 211 & 15 & 37 & 74 & 35 & 88 & 176 \\
\hline \begin{tabular}{|l|} 
Sinoe \\
\end{tabular} & $\begin{array}{l}936,783 \\
\end{array}$ & 55,757 & 9,174 & 13,518 & 22,692 & 33,065 & 20 & 50 & 99 & 7 & 17 & 35 & 17 & 41 & 83 \\
\hline River Gee & $\begin{array}{l}619,854 \\
\end{array}$ & 35,153 & 5,589 & 0 & 5,589 & 29,564 & 18 & 44 & 89 & 6 & 16 & 31 & 15 & 37 & 74 \\
\hline Gbarpolu & 923,776 & 212,837 & 12,801 & 0 & 12,801 & 200,036 & 120 & 300 & 600 & 42 & 105 & 210 & 100 & 250 & 500 \\
\hline Total & $9,605,327$ & $3,665,243$ & 485,906 & 126.136 & 612,042 & $3,053,202$ & 1.832 & 4.580 & 9.160 & 641 & 1.603 & 3206 & 1527 & 3.817 & 7633 \\
\hline
\end{tabular}

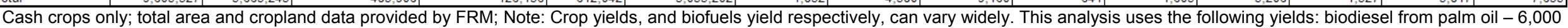

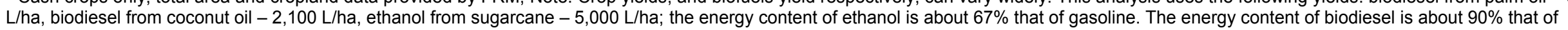
petroleum diesel.

Table 12. Bio-power Potential in Liberia

\begin{tabular}{|c|c|c|c|c|c|c|c|c|c|c|c|c|c|c|c|}
\hline \multirow[b]{2}{*}{ County } & \multirow[b]{2}{*}{$\begin{array}{l}\text { Total Area } \\
\text { (ha) }\end{array}$} & \multirow[b]{2}{*}{$\begin{array}{l}\text { Cropland } \\
\text { (ha) }\end{array}$} & \multicolumn{3}{|c|}{ Cropland Under Cultivation (ha) } & \multirow[b]{2}{*}{$\begin{array}{c}\text { Available } \\
\text { Cropland (ha) }\end{array}$} & \multicolumn{3}{|c|}{ Electricity from oil palm residues (GWh/yr) } & \multicolumn{3}{|c|}{ Electricity from coconut residues (GWh/yr) } & \multicolumn{3}{|c|}{ Electricity from sugracane residues (GWh/yr) } \\
\hline & & & $\begin{array}{l}\text { Area Planted by } \\
\text { Small Household } \\
\text { Farms }\end{array}$ & $\begin{array}{l}\text { Area Planted by } \\
\text { Large Plantations }\end{array}$ & Total & & $\begin{array}{c}10 \% \text { of } \\
\text { Available } \\
\text { Cropland }\end{array}$ & $\begin{array}{l}25 \% \text { of } \\
\text { Available } \\
\text { Cropland }\end{array}$ & $\begin{array}{c}50 \% \text { of } \\
\text { Available } \\
\text { Cropland }\end{array}$ & $\begin{array}{c}10 \% \text { of } \\
\text { Available } \\
\text { Cropland }\end{array}$ & $\begin{array}{c}25 \% \text { of } \\
\text { Available } \\
\text { Cropland }\end{array}$ & $\begin{array}{c}50 \% \text { of } \\
\text { Available } \\
\text { Cropland }\end{array}$ & $\begin{array}{c}10 \% \text { of } \\
\text { Available } \\
\text { Cropland }\end{array}$ & $\begin{array}{c}25 \% \text { of } \\
\text { Available } \\
\text { Cropland }\end{array}$ & $\begin{array}{c}50 \% \text { of } \\
\text { Available } \\
\text { Cropland }\end{array}$ \\
\hline Bomi & 212,188 & 200,064 & 1,858 & 10,000 & 11,858 & 188.206 & 1,085 & 2.713 & 5,425 & 28 & 70 & 139 & 547 & 1,367 & 2,733 \\
\hline Bong & 838,360 & 670,361 & 53,451 & 607 & 54,058 & 616,303 & 3,553 & 8,883 & 17,766 & 91 & 228 & 456 & 1,790 & 4,475 & 8,950 \\
\hline Grand Bassa & 747,785 & 449,696 & 28.989 & 27,759 & 56,748 & 392.948 & 2,266 & 5,664 & 11,328 & 58 & 145 & 291 & 1.141 & 2.853 & 5,707 \\
\hline Grand Cape Mount & 496.254 & 189,867 & 5,181 & 2.833 & 8.014 & 181.853 & 1.048 & 2.621 & 5.242 & 27 & 67 & 135 & 528 & 1,320 & 2,641 \\
\hline Grand Gedeh & $1,028,201$ & 41,482 & 13,048 & 2,186 & 15,234 & 26,248 & 151 & 378 & 757 & 4 & 10 & 19 & 76 & 191 & 381 \\
\hline Grand Kru & $\begin{array}{r}\frac{200,201}{369,909} \\
\end{array}$ & $\begin{array}{r}4,402 \\
117,036\end{array}$ & $\begin{array}{r}20,264 \\
2,264\end{array}$ & & $\frac{15,204}{2,264}$ & $\begin{array}{r}20,240 \\
114,772\end{array}$ & $\mid 662$ & $\begin{array}{r}510 \\
1.654\end{array}$ & \begin{tabular}{|l|}
3,309 \\
\end{tabular} & \begin{tabular}{r|r}
4 \\
17
\end{tabular} & 42 & 85 & 333 & 833 & \begin{tabular}{r|r|}
1.667 \\
\end{tabular} \\
\hline \begin{tabular}{|l|l} 
Lofa \\
\end{tabular} & \begin{tabular}{|c|}
$1,031,743$ \\
\end{tabular} & 440,149 & 68,789 & 17,428 & $\begin{array}{l}2,217 \\
86,217\end{array}$ & 353,931 & 2,041 & 5,101 & \begin{tabular}{|c|}
10,203 \\
\end{tabular} & 52 & 131 & 262 & 1,028 & 2,570 & 5,140 \\
\hline Margibi & $\begin{array}{r}, 031,222 \\
281\end{array}$ & 239,856 & 29.280 & 27,500 & 56,780 & 183.076 & $\frac{2,0+1}{1,056}$ & 2,639 & \begin{tabular}{|c|}
5,278 \\
5
\end{tabular} & 27 & 68 & 136 & $\begin{array}{r}, 020 \\
532\end{array}$ & 1,329 & 2,659 \\
\hline Maryland & $\begin{array}{l}218,2219 \\
21,81\end{array}$ & 117,641 & $\mid 16,843$ & $\mid 10,880$ & 27,723 & 89.917 & 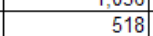 & $\begin{array}{l}, 055 \\
1,296\end{array}$ & 2,592 & 13 & 33 & 67 & 261 & $\begin{array}{r}, \sqrt{2} \\
653 \\
\end{array}$ & 1,306 \\
\hline Montserrado & \begin{tabular}{|l|l|l|l|}
181,113 \\
\end{tabular} & 167,077 & \begin{tabular}{|l|}
166,652 \\
\end{tabular} & 425 & \begin{tabular}{|l|}
167,077 \\
\end{tabular} & & 0 & & & 0 & 0 & 0 & 0 & 0 & \\
\hline \begin{tabular}{|l} 
Nimba \\
\end{tabular} & $1,191,121$ & 652,135 & 66,145 & 13000 & 79.145 & 572.990 & 3.304 & 8.259 & 16.518 & 85 & 212 & $\frac{0}{424}$ & 1.664 & 4.161 & 8.321 \\
\hline River Cess & $\begin{array}{r}, 17,1,199 \\
528,\end{array}$ & $\begin{array}{l}76,132 \\
\end{array}$ & $\begin{array}{l}5,840 \\
\end{array}$ & & 5,840 & 70,291 & 405 & $\begin{array}{l}1,013 \\
1,013\end{array}$ & 2,026 & 10 & 26 & 52 & 204 & 510 & 1,021 \\
\hline \begin{tabular}{|l} 
Riner Less \\
Sinoe
\end{tabular} & $\begin{array}{l}5 \angle 0,199 \\
936,783\end{array}$ & 55,757 & $\begin{array}{l}3,064 \\
9,174\end{array}$ & 13.518 & \begin{tabular}{r|}
5,004 \\
22,692 \\
\end{tabular} & 33,065 & $\begin{array}{l}405 \\
191 \\
\end{array}$ & $\begin{array}{r}1,013 \\
477\end{array}$ & $\begin{aligned} 2,020 \\
953\end{aligned}$ & $\frac{10}{5}$ & $\begin{array}{l}20 \\
12\end{array}$ & $\frac{52}{24}$ & $\frac{204}{96}$ & 240 & $\begin{array}{r}\mid, 021 \\
480 \\
\end{array}$ \\
\hline \begin{tabular}{|l|l} 
River Gee \\
\end{tabular} & \begin{tabular}{|l|l|}
619,854 \\
\end{tabular} & 35,153 & \begin{tabular}{|l|l|}
5,589 \\
\end{tabular} & & $\begin{array}{r}5,589 \\
5,03\end{array}$ & 29,564 & 170 & 426 & 852 & 4 & 11 & 22 & 86 & 2415 & 429 \\
\hline Gbarpolu & 923,776 & 212,837 & 12,801 & 0 & 12,801 & 200,036 & 1,153 & 2,883 & 5,766 & 30 & 74 & 148 & 581 & 1,453 & 2,905 \\
\hline \begin{tabular}{|l|} 
Total \\
Total
\end{tabular} & \begin{tabular}{|c|}
950,327 \\
$9,605,30$
\end{tabular} & $\begin{array}{r}21,031 \\
3,665,243 \\
\end{array}$ & \begin{tabular}{|l|}
485,906 \\
48,9
\end{tabular} & 126,136 & \begin{tabular}{r|}
612,042 \\
612,0
\end{tabular} & $\begin{array}{r}200,050 \\
3,053,202\end{array}$ & $\mid$\begin{tabular}{|l|l|}
17.603 \\
\end{tabular} & $\begin{array}{l}, 000 \\
44,007\end{array}$ & \begin{tabular}{|l|}
5,10015 \\
88,015
\end{tabular} & 452 & $\begin{array}{r}1.130 \\
\end{array}$ & 2.260 & \begin{tabular}{|l|l|}
8.868 \\
\end{tabular} & $\begin{array}{l}, 430 \\
22,170\end{array}$ & 44,340 \\
\hline
\end{tabular}

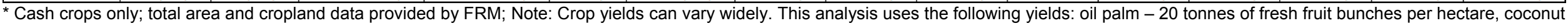

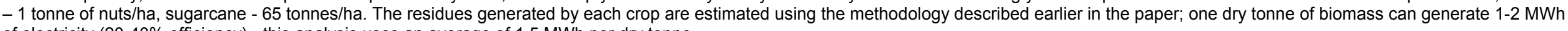
of electricity (20-40\% efficiency) - this analysis uses an average of $1.5 \mathrm{MWh}$ per dry tonne. 
Although Jatropha holds considerable potential as a diesel substitute, there are many uncertainties surrounding its cultivation, primarily because while it grows abundantly in the wild, it has never been domesticated. The establishment, management, and productivity of the plant are not well understood and documented. Until this knowledge is improved, it is perhaps best to think of Jatropha as a secondary crop (as an intercrop or hedge), as part of rural livelihoods and local energy projects, and not as a monoculture. If used as an intercrop, Jatropha can provide an additional source of income for small farmers. For example, in Peru there are plans for intercropping the plant with coffee; in the Philippines with coconut trees. The United States has a trial orange farm intercropped with Jatropha. In Madagascar, farmers traditionally use it to support the climbing stem of vanilla. Jatropha can also be intercropped with banana/plantains and used for attracting scarring beetles so they don't scratch the fruits and lower their selling value. The range of oil yield per land unit varies widely in the literature-between 500 and 1,500 liters per hectare (some sources even suggest 2,000 liters/ha). If planted as a fence, its yield is approximately equal to one-tenth the yield of the area enclosed by the fence (Krypton Systems 2008). For example, if 5 ha farm is fenced with Jatropha, the collected oil would be about $500 \mathrm{~L}$, assuming a yield of $1,000 \mathrm{~L} / \mathrm{ha}$. The oil-to-biodiesel ratio is almost $1: 1$, therefore about $500 \mathrm{~L}$ of biodiesel could be produced on a 5 ha farm.

\section{Caveats}

To calculate the forest and cropland area in Liberia, the project relies exclusively on the 2004 GIS data provided by Liberia's Environmental Protection Agency. The data was created by the French firm Forest Resources Management (FRM). However, the spatial distribution of the land cover types in this dataset (Figure 9) is different than those illustrated by Google's latest satellite imagery (Figure 10). Therefore, additional work is needed to ensure accurate and up-to-date information on the land cover distribution in Liberia for a more precise analysis of the land availability and biomass resource potential. 


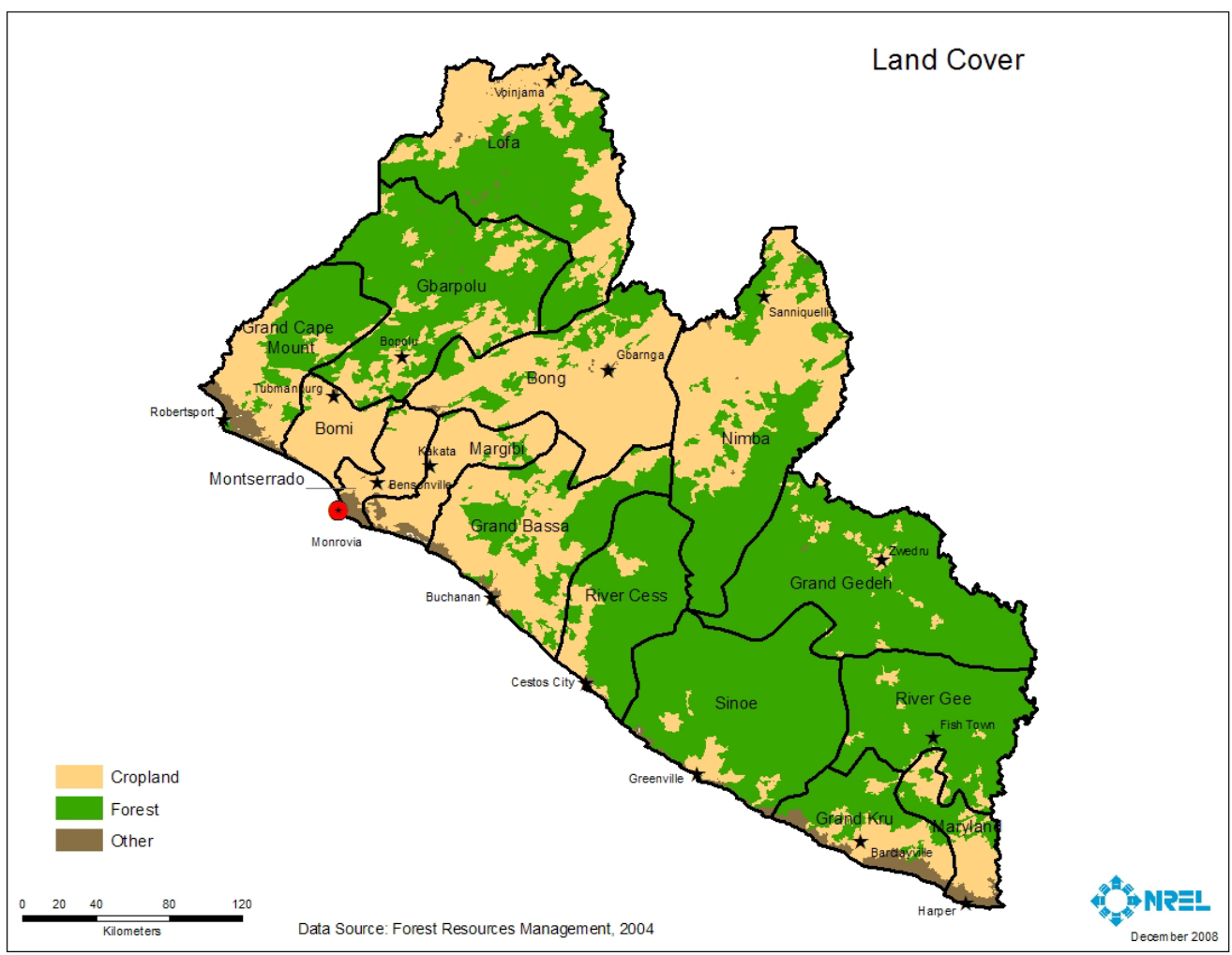

Figure 9. Land Cover

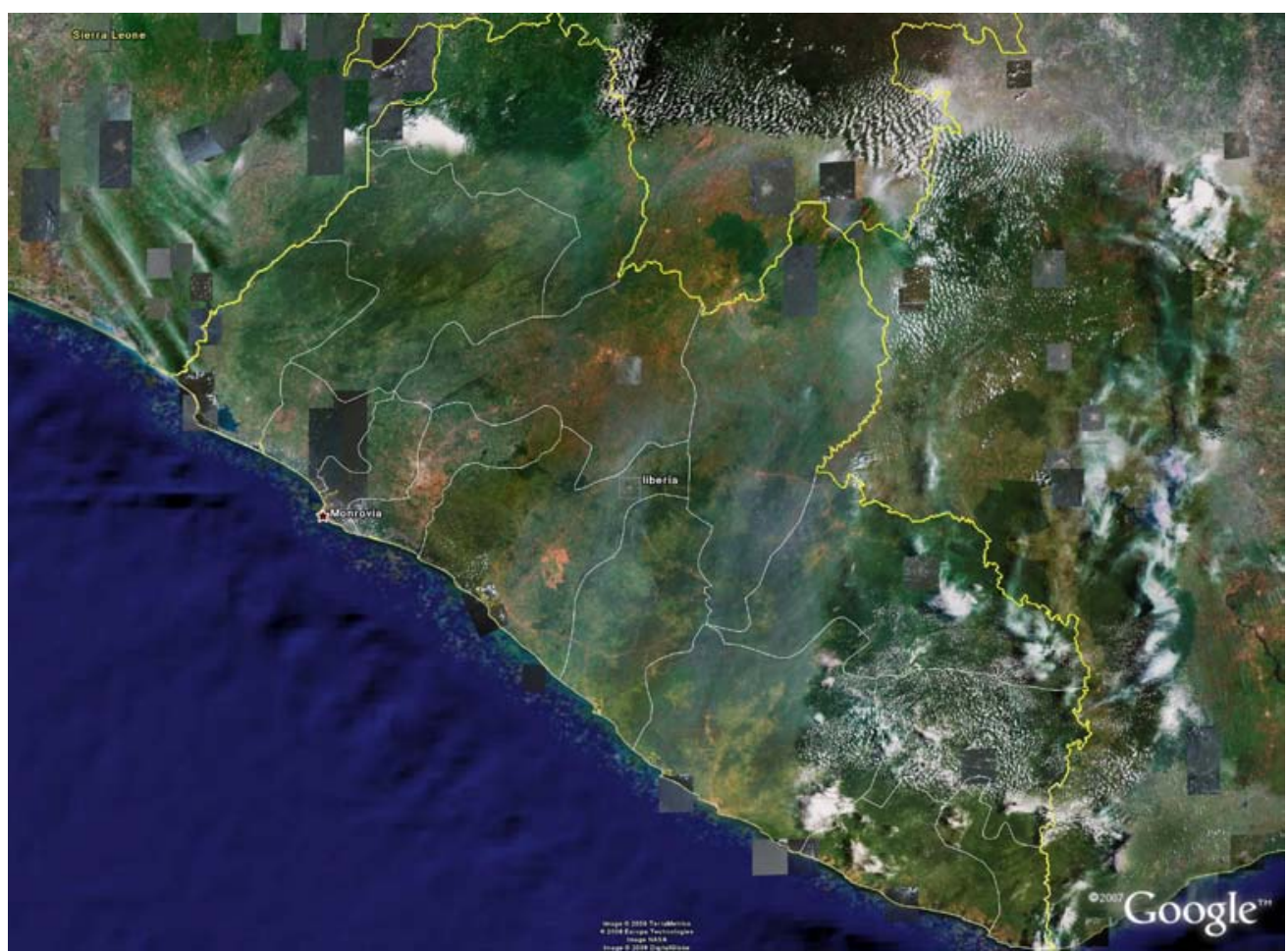

Figure 10. Satellite Imagery 


\section{Socio-Economic and Environmental Implications of Biomass Resource Development in Liberia}

The local production and use of biomass resources as substitute for fossil-based fuels offers many attractive benefits for Liberia; however, they could also have negative effects if not managed properly. The following socio-economic and environmental implications should form the basis of a more detailed study on the impact of biomass resource development to guide appropriate national policies and measures.

\section{Socio-Economic Implications}

The global quest for alternative sources of energy, especially in the area of transportation fuels, presents an opportunity for local and foreign investments in Liberia, as well as increased export earnings. Pursuing Liberia's biomass potential would have a domino effect: it would boost agricultural development, boost technological advancement, and bring job opportunities, thereby improving quality of life. Also, because biomass resources can be converted to liquid and gaseous fuels, electricity, and process heat, they can increase access to modern forms of energy for the Liberian population. Moreover, producing biomass resources domestically reduces the country's dependence on foreign energy sources and vulnerability to supply disruptions.

Biomass resource cultivation, harvesting, and processing could have a direct impact on rural development and poverty reduction. It could improve rural livelihoods by providing new income opportunities to families and communities growing biomass, or through direct employment. Using biomass resources in stand-alone power generation units could insulate poor rural households from energy price fluctuations, allowing for an independent electricity source.

Although there are numerous benefits, the expansion of biomass resource development could also have some negative socio-economic effects on rural communities. A study by the Worldwatch Institute points out that in the biofuels industry, most jobs are found at plantations where wages and working conditions can be very poor (Worldwatch 2008). Also, companies can make false promises about jobs for local communities. The study found that small farms could be more effective in job development than large scale plantations, stating that small farming systems in Indonesia provide livelihoods for 260 times as many people per hectare of land as oil palm plantations. Depopulation of regions could also be associated with large-scale monoculture plantations due to depletion of traditional wood and food resources.

\section{Environmental Implications}

The local production and use of biomass resources offers many benefits to the environment, including offsetting greenhouse gas (GHG) emissions associated with burning fossil fuels, waste utilization, and erosion control among others. Clearly biomass technology directly benefits the environment while helping solve pressing environmental problems.

Using biomass to produce energy is carbon neutral because it releases roughly as much carbon dioxide $\left(\mathrm{CO}_{2}\right)$ as it takes in. For every $\mathrm{MWh}$ of biomass power, approximately 1.6 tonnes of $\mathrm{CO}_{2}$ are avoided (Morris 2008). This figure includes 0.8 tons/MWh from avoided fossil fuel use and 0.8 tons/MWh avoided from biomass decomposition or open burning. Carbon dioxide is the principal GHG that causes global warming, and the increasing levels of its concentration in the atmosphere are of great concern. The use of biomass resources, managed in a sustainable way, would reduce $\mathrm{CO}_{2}$ emissions and help tackle global warming. 
While $\mathrm{CO}_{2}$ is the principal $\mathrm{GHG}$, methane is a close second. According to the Intergovernmental Panel on Climate Change, methane is about 21 times as effective as $\mathrm{CO}_{2}$ at trapping heat in the atmosphere. Therefore, reducing 1 tonne of methane has the same positive effect as reducing 21 tonnes of $\mathrm{CO}_{2}$. Methane is the principal component in biogas, and as described earlier, it is produced by anaerobic digestion or fermentation of biodegradable materials such as manure, sewage, and MSW. Biogas capture and utilization presents an attractive opportunity for waste management in Liberia because it is a valuable renewable energy source that can be used to provide electricity while reducing methane emissions. This technology could be particularly effective in handling rubber wastewater, which is otherwise dumped in rivers, creating serious pollution problems. The green byproduct from biogas digesters are rich in nutrients and could be reapplied to rubber plantations. As Liberia plans to further develop the palm oil industry, biogasto-electricity technology could be used to handle the industry's waste. Another waste management problem with environmental and human health implications in Liberia that could be tackled with biomass technology is the disposal of MSW. The use of waste as an energy source provides two important benefits: environmentally safe waste management and disposal, as well as clean electric power generation. Waste-to-energy combustion reduces the volume of trash by about $90 \%$, decreasing the amount of land required for garbage disposal by $90 \%$.

Biomass resource development, under proper management, could be very beneficial in managing soil erosion. Afforestation and reforestation activities could prevent the soils from being washed or blown away, and residues from production and harvesting could provide additional soil protection as well as other benefits such as nutrient supply and moisture retention.

Some of the negative environmental impacts associated with the production and use of biomass resources include deforestation, increased GHG emissions, loss of biodiversity, and soil erosion. Deforestation is caused primarily by shifting cultivation (land clearing for crop production) and excessive logging. This could have reverse GHG effects: first, clearing is often done by burning, which releases $\mathrm{CO}_{2}$; and second, once removed, the trees no longer contribute to carbon storage. Liberia's population relies almost entirely on biomass resources (firewood and charcoal) for its energy needs; therefore, using alternative sources is critical to forest sustainability. Charcoal, for example, is produced mainly from trees, so using alternative sources like coconut husks and banana peels would relieve the pressure on native forests. Deforestation also leads to soil erosion and decline in biodiversity. Additionally, loss of biodiversity could result from an increase in monoculture crops and plantations. A study by the Integrated Framework in 2008 stated that where forest has been replaced by oil palm or rubber trees, up to $80 \%$ of reptile, mammal, and bird species previously found cannot be supported by the new environment. The use of pesticides and herbicides also devastates fauna and flora. The study also points out that the palm oil and rubber industries are rife with unsustainable environmental practices. As Liberia plans to revive and expand these industries, proper planning and management will be required to ensure protection of its rich biodiversity. 


\section{Conclusions}

This study estimates the biomass resources currently and potentially available in Liberia and evaluates their power generation and transportation fuels production potential. A variety of biomass resources exist in the country with large quantities and opportunities for expansion. As illustrated in Table 13, these resources are more than enough to cover the country's annual electricity consumption of 297 GWh (CIA 2005) and oil consumption of 206 dam $^{3}$ (Index Mundi 2005). While the contribution of food crop residues, animal manure, and MSW is small in comparison to other resources at a national level, they could play a valuable role in stand-alone electricity applications and be particularly effective for households in remote rural areas. On the other hand, cash crop and forest residues, resulting mainly from medium and large enterprises, provide opportunities for large-scale centralized power generation.

Considering the potential biomass resources or the expansion of key existing resources such as oil palm, coconut, and sugarcane, the study evaluates their fuel and power production potential on available cropland. The study estimates that of the total cropland in Liberia, only $6 \%$ is currently cultivated and that the remaining cropland amounts to some 3 million hectares. It is unrealistic to assume that all of this land would go under cash crop cultivation-a portion of it may go under afforestation to maintain forest ecosystems and their unique biodiversity, or be used for food crops production and other agricultural activities, or be converted to urban land. Therefore, the study evaluates the fuel and power production potential of biomass resources under three scenarios: using $10 \%, 25 \%$, and $50 \%$ of the available cropland for cash crops expansion. Table 13 illustrates the conservative results of this analysis-using up to $30 \%$ of the available cropland for expanded cash crops production. If this percentage increases, it would double or triple the bio-power and biofuels production potential as shown by the different analysis scenarios in the previous chapter.

Table 13. Bio-power and Biofuels from Existing and Potential Biomass Resources

\begin{tabular}{|c|c|c|c|}
\hline Existing Resources & $\begin{array}{c}\text { Bio-power } \\
\text { (GWh/yr) }\end{array}$ & $\begin{array}{l}\text { Biodiesel } \\
\text { (dam3/yr) }\end{array}$ & $\begin{array}{l}\text { Ethanol } \\
\text { (dam3/yr) }\end{array}$ \\
\hline Food Crop Residues & 188 & & \\
\hline Cash Crop Residues & 5,889 & & \\
\hline Biogas from Animal Manure & 219 & - & \\
\hline Forest Residues & 15,248 & - & \\
\hline MSW (biogenic material only) & 52 & & \\
\hline Total & 21,596 & & \\
\hline \multicolumn{4}{|l|}{ Potential Resources } \\
\hline Vegetable Oils* & 4,946 & 2,473 & \\
\hline Sugarcane & & & 1,527 \\
\hline Crop residues & 26,923 & & 5,385 \\
\hline
\end{tabular}

"_" Not Applicable; * Includes palm and coconut oil - using 10\% of available cropland for oil palm and $10 \%$ for coconut; ${ }^{* *}$ Using $10 \%$ of available cropland; ${ }^{* * *}$ Includes oil palm, coconut, and sugarcane residues - using $30 \%$ of available land ( $10 \%$ for each crop); 1 liter of vegetable oil $=2 \mathrm{kWh}$ at $21 \%$ conversion efficiency; 1 tonne of lignocellulosic biomass yields $\sim 300$ liters of ethanol. Note: Currently, Liberia produces vegetable oils, which are mostly used in food consumption, medicinal, and few other purposes. Thus, it is unlikely that these resources would be used as a diesel substitute in the near future. 
The contribution of each county to the total amount of bio-power and biofuels from existing and potential biomass resources is presented in Table 14. With regard to existing resources, Nimba County ranks first with the highest amount, thus the highest electricity potential, followed by Montserrado, Bong, Margibi, Grand Bassa, and so on. Regarding future biomass resources, the quantity and their respective bioenergy potentials are highly dependent on the available cropland in each county. The ranking is slightly different-Bong County is leading, followed by Nimba, Grand Bassa, Lofa, Gbarpolu, etc.

Table 14. Bio-power and Biofuels from Existing and Potential Biomass Resources by County

\begin{tabular}{|c|c|c|c|c|c|c|c|c|}
\hline \multirow[b]{2}{*}{ County } & \multicolumn{4}{|c|}{ Existing Resources } & \multicolumn{4}{|c|}{ Potential Resources } \\
\hline & $\begin{array}{c}\text { Bio-Power from } \\
\text { Food Crop } \\
\text { Residues (GWh/yr) }\end{array}$ & $\begin{array}{c}\text { Bio-Power from } \\
\text { Cash Crop } \\
\text { Residues* (GWh/yr) }\end{array}$ & $\begin{array}{c}\text { Bio-Power from } \\
\text { Forest Residues } \\
\text { (GWh/yr) }\end{array}$ & Rank & $\begin{array}{l}\text { Biodiesel }^{\star \star} \\
\text { (dam3/yr) }\end{array}$ & $\begin{array}{l}\text { Ethanol } \\
\text { (dam3/yr) }\end{array}$ & $\begin{array}{c}\text { Bio-Power from Cash } \\
\text { Crop Residues } \\
\text { (GWh/yr) }\end{array}$ & Rank \\
\hline Bomi & 1.4 & 25.1 & 0 & 11 & 152 & 94 & 1,660 & 6 \\
\hline Bong & 32.6 & 105.5 & 0.04 & 3 & 499 & 308 & 5,435 & 1 \\
\hline Grand Bassa & 8.2 & 66.2 & 0.15 & 5 & 318 & 196 & 3,465 & 3 \\
\hline Grand Cape Mount & 1.6 & 32.5 & 0.15 & 10 & 147 & 91 & 1,604 & 8 \\
\hline Grand Gedeh & 6.4 & 9.8 & 3.88 & 12 & 21 & 13 & 231 & 14 \\
\hline Grand Kru & 1.6 & 5.5 & 1.15 & 15 & 93 & 57 & 1,012 & 9 \\
\hline Lofa & 18.9 & 46.9 & 0.88 & 6 & 287 & 177 & 3,121 & 4 \\
\hline Margibi & 8.8 & 114.7 & 0 & 4 & 148 & 92 & 1,614 & 7 \\
\hline Maryland & 8.8 & 32.2 & 0.24 & 8 & 73 & 45 & 793 & 10 \\
\hline Montserrado & 35.8 & 184.9 & 0 & 2 & 0 & 0 & 0 & 15 \\
\hline Nimba & 45.6 & 213.3 & 1.76 & 1 & 464 & 286 & 5,053 & 2 \\
\hline River Cess & 2.1 & 8.5 & 2.88 & 14 & 57 & 35 & 620 & 11 \\
\hline Sinoe & 5.1 & 32.1 & 0.97 & 9 & 27 & 17 & 292 & 12 \\
\hline River Gee & 3.9 & 12.0 & 2.19 & 13 & 24 & 15 & 261 & 13 \\
\hline Gbarpolu & 7.4 & 40.5 & 0.98 & 7 & 162 & 100 & 1,764 & 5 \\
\hline
\end{tabular}

1 dry tonne of biomass $=1.5 \mathrm{MWh}$ of electricity (20-40\% efficiency); ${ }^{*}$ The total doesn't add up to total for the whole country. The analysis by county excludes residues from replanting. There would be different removal rates depending on local tree stock conditions; * Includes palm and coconut oil - using $10 \%$ of available cropland for oil palm and $10 \%$ for coconut tree; *** Using $10 \%$ of available cropland for sugarcane; ${ }^{* * *}$ Includes oil palm, coconut, and sugarcane residues - using $30 \%$ of available cropland - $10 \%$ for each crop.

The local production and use of biomass resources as substitute for fossil-based fuels offers many attractive benefits for Liberia. The socio-economic benefits include attracting investment opportunities, job creation, rural development, and poverty reduction. Benefits to the environment include offsetting the GHG emissions associated with burning fossil fuels, waste utilization, and erosion control. However, if not managed properly, biomass resource development could have negative environmental impacts such as deforestation, increased GHG emissions, loss of biodiversity, and soil erosion. The socio-economic and environmental implications briefly described in this paper should form the basis of a more detailed study on the impact of biomass resources development in order to guide appropriate national policies and measures. 


\section{References}

1. Adams, M.; Dougan, J. (1981). "Biological management of coffee processing." Tropical Science, Vol.123, pp.178-196.

2. African Agriculture in Liberia (July 2007 - August 2008). Accessed October 2008. http://africanagriculture.blogspot.com/search/label/Liberia

3. Bax, P. (February 27, 2008). Liberia Signs Accord with Firestone; Raises Taxes, Cuts Term. New York, N.Y.: Bloomberg. http://www.bloomberg.com/apps/news?pid=20601116\&sid=aNM4h3HMD8Ss\&refer=afri ca

4. Brandolini, G.; Tigani, M. (December 2006). Liberia Environmental Profile. Created for the Government of Liberia and the European Commission. http://ec.europa.eu/development/icenter/repository/liberia CEP preliminary report.pdf

5. Central Intelligence Agency. Electricity Consumption by Country. The World Factbook online. Accessed October 2008. https://www.cia.gov/library/publications/the-worldfactbook/fields/2042.html

6. Duke, J. (1983). Handbook of Energy Crops. Purdue University. Accessed October 2008. http://www.hort.purdue.edu/newcrop/duke energy/theobroma cacao.html

7. Executive Mansion, Republic of Liberia (July 2008). County Development Agendas. Executive Mansion online. Accessed October 2008. http://www.emansion.gov.Ir/content.php?sub=County\%20Development\%20Agendas\&rel ated $=$ CDAs

8. Food and Agricultural Organization (FAO). Commodities by Country - Liberia. Accessed October 2008. http://www.fao.org/es/ess/top/country.html?lang=en

9. Food and Agricultural Organization (FAO) (February 2006). Crop and Food Security Assessment for Liberia.

10. Food and Agricultural Organization (FAO) (December 2000). Crop and Food Supply Assessment Mission to Liberia.

11. Food and Agricultural Organization (FAO) (January 1999). Crop and Food Supply Situation in Liberia. Accessed October 2008. http://www.fao.org/docrep/004/x1015e/x1015e00.htm

12. Forest Resources Management (FRM), Land-cover data in GIS format, 2004

13. Forestry Development Authority (FDA) (March 2008). Available Logging Contracts. Accessed December 2008. Accessed October 2008. http://www.fda.gov.Ir/content.php?sub=Bids\&related=Bids

14. Forestry Development Authority (FDA) (2007). National Forest Management Strategy, Monrovia. Accessed October 2008. http://www.fda.gov.Ir/doc/NFMgmtStrategy.pdf

15. Global Security (1985). Commercial Crops in Liberia, Accessed October 2008. http://www.globalsecurity.org/military/library/report/1985/liberia 3 commercialcrops.htm

16. Index Mundi, Liberia Oil Consumption, Accessed December 2008, http://www.indexmundi.com/liberia/oil consumption.html

17. Integrated Framework (IF), Liberia - Tapping Nature's Bounty for the Benefit of All, Diagnostic Trade Integration Study, June 2008, http://www.integratedframework.org/

18. ITTAS Consultancy (May 2008). Post Harvest Crop Assessment in Liberia (Rice and Cassava).

19. Jubah, K. (2007). Interim Rubber Plantations Management Performance, November 2007. Ministry of Agriculture (MOA).

http://www.moa.gov.Ir/doc/Guthrie Cavalla Final Report 07.pdf

20. Koopmans, A.; Koppejan, J. (January 1997). "Agricultural and Forest Residues Generation, Utilization, and Availability." Presented at the Regional Consultation on 
Modern Applications of Biomass Energy conference at the Regional Wood Energy Development Programme, Kuala Lumpur, Malaysia.

21. Krypton Systems Pvt. Ltd., Commercial Opportunity of Jatropha, Accessed December 2008, http://www.jatrophabiofuel.com/Commercial\%200pportunity\%20$\% 20$ Project $\% 20$ Cost.htm

22. Liberia Institute of Statistics and Geo-Information Services (LISGIS) (June 2008). 2008 National Population and Housing Census: Preliminary Results. Executive Mansion, Republic of Liberia. http://www.emansion.gov.Ir/doc/census 2008provisionalresults.pdf

23. Manapol, P. (November 2007). "SRE President Speaks At Liberia Workshop." Sustainable Rural Enterprise (SRE) blog. http://coconutsgalore.blogspot.com/

24. Mano Properties \& Investment, Inc. (MPI) (2007). Logging and Timber in Liberia. Accessed November 2008. http://us-africa.tripod.com/mrbc/logging.html

25. Ministry of Agriculture (MOA) (2007). "Comprehensive Assessment of the Agricultural Sector - Synthesis Report." MOA, Vol. 1

26. Monrovia City Corporation (August 2004). Waste Management Plan for Monrovia. United Nations Children's Fund.

27. Morris, G., Bioenergy and Greenhouse Gases, Pacific Institute, May 2008, http://www.usabiomass.org/docs/legislative/One\%20pager\%20-\%20Morris\%20FINAL\%207-24-08.doc

28. Paye-Layleh, J. (February 17, 2004). "Liberian rebels take over, loot rubber plantation." Associated Press (AP). http://www.highbeam.com/doc/1P1-91188698.html

29. PÖYRY Environment GmbH (November 2007). "Solid Waste Management in Greater Monrovia." Draft report prepared for the Monrovia City Corporation and the World Bank.

30. Sajjakulnukit, B., et al. (2005). "Assessment of sustainable energy potential of nonplantation biomass resources in Thailand." Biomass and Bioenergy Journal, Vol. 29, pp. 214-224.

31. Republic of Liberia (October 2006). Comprehensive Food Security and Nutrition Survey. Monrovia, Liberia: United Nations World Food Programme. http://www.reliefweb.int/rw/rwb.nsf/db900sid/RMOI-6VK3RV?OpenDocument

32. Sheikh, N. (1989). The preservation of banana crop residues through ensiling process. Department of Animal Production, Faculty of Agriculture, Somali National University. http://www.fao.org/wairdocs/ILRI/x5490E/x5490e0v.htm

33. Smillie, I.; Brownell, A. (July 20070. Land Grabbing and Land Reform: Diamonds, Rubber and Forests in the New Liberia. Partnership Africa Canada (PAC) and the Association of Environmental Lawyers of Liberia (Green Advocates). http://www.pacweb.org/e/images/stories/documents/17 liberia.pdf

34. Smith, E. (May 2008). Assessment on the Small-scale Livestock Sub-sector in Liberia. Report for the Food and Agricultural Organization.

35. Taylor \& Francis Group (2003). Africa South of the Sahara 2004. London: Routledge.

36. United Nations Environmental Programme (UNEP). Atlas of Our Changing Environment, Harbel Rubber Plantation - Liberia. Accessed October 2008. http://na.unep.net/atlas/

37. United Nations Environmental Programme (UNEP) (July 2007). Assessment of Solid Waste Management in Liberia. UNEP Post Conflict Assessment Web site online. Accessed October 2008. http://postconflict.unep.ch/publications/Liberia waste.pdf

38. United Nations (May 2006). Human Rights in Liberia's Rubber Plantations: Tapping into the Future. United Nations online. Accessed October 2008. http://unmil.org/documents/human rights liberiarubber.pdf

39. Woods, J.; Blundell, A.G.; Simpson, R. (January 2008). Investment in the Liberian Forest Sector: A Roadmap to Legal Operations in Liberia. Washington, D.C.: Forest Trends. http://www.forest-trends.org/documents/publications/LiberiaGuidelinesEng.pdf 
40. The World Bank (June 2008). Liberia - Tapping Nature's Bounty for the Benefit of All, Diagnostic Trade Integration Study.

41. The World Bank (1999). Solid Waste Landfills in Middle- and Lower- Income Countries: A Technical Guide to Planning, Design, and Operation. Washington, D.C.: The World Bank. Technical Paper No. 426, pp. 248.

42. Worldwatch Institute, Jobs in Renewable Energy, July 2008, http://www.worldwatch.org/node/5821 


\section{Appendix A. Estimating Food Crop Residues by County}

County level crop production data is only available for rice and cassava from organizations such as FAO and the United Nations. Other crop data is available at a national level. The method described below is used in this study to disaggregate the national level statistics of crop production to county level. Then, crop residues are calculated using a crop-to-residue ratio as illustrated previously in Table 1.

The assumption is made that all families in any one county growing a particular crop have the same average yield and corresponding residue. Therefore, by knowing the number of farming families in a county and the percentage of families that grow a particular crop (Table 15), that county's contribution to the entire country's production can be calculated and the resulting residues estimated. For example: There are about 1,556 families growing rice in Bomi County $(2,551 * 0.61)$. Dividing that number by the total number of families growing rice in Liberia $(206,503)$ gives us the percentage of rice growing families in Bomi County from all rice growing families in Liberia $(0.75 \%)$. This percentage is then multiplied by the country's rice production of 110,000 tonnes/year to give us the production of rice in Bomi County (829 tonnes/year). Further, applying crop to residue ratios (Table 1) gives us the amount of rice straw (325 dry tonnes/year) and husk (197 dry tonnes/year) in Bomi County, or total of 521 dry tonnes of crop residues per year (Table 2).

Another method to estimate the food crop production and residues by county is using the number of farming families, the farm size for each crop, and average crop yield. However, farm size and yield data in Liberia is available only for rice and cassava with a great uncertainty. Because the available information on average farm size (Table 15) doesn't indicate what portion of the farm is used to grow each crop, the results using this method may be misleading, and is therefore presented only as a reference.

Table 15. Farming Families Growing Food Crops in Liberia, 2005

\begin{tabular}{|c|c|c|c|c|c|c|c|}
\hline \multirow{2}{*}{ County } & \multirow{2}{*}{$\begin{array}{l}\text { Number of } \\
\text { Farming } \\
\text { Families }\end{array}$} & \multirow{2}{*}{$\begin{array}{l}\text { Average Farm } \\
\text { Size (ha) }\end{array}$} & \multicolumn{5}{|c|}{$\%$ of Farming Families Growing Food Crops } \\
\hline & & & Rice & Cassava & \begin{tabular}{|c|} 
Other Roots and \\
Tubers
\end{tabular} & Maize & Groundnuts \\
\hline Bomi & 2,551 & 0.73 & 61 & 84 & 8 & 8 & 1 \\
\hline Bong & 37,736 & 1.42 & 88 & 62 & 17 & 19 & 4 \\
\hline Grand Bassa & 18,850 & 1.54 & 60 & 87 & 2 & 0 & 0 \\
\hline Grand Cape Mount & 4,572 & 1.13 & 53 & 50 & 9 & 1 & 0 \\
\hline Grand Gedeh & 11,515 & 1.13 & 93 & 35 & 3 & 5 & 0 \\
\hline Grand Kru & 2,945 & 0.77 & 82 & 82 & 10 & 11 & 0 \\
\hline Lofa & 31,477 & 2.19 & 95 & 17 & 6 & 7 & 1 \\
\hline Margibi & 24,117 & 1.21 & 33 & 79 & 1 & 12 & 0 \\
\hline Maryland & 14,864 & \begin{tabular}{l|l}
1.13 \\
\end{tabular} & 74 & 78 & 10 & 14 & 0 \\
\hline Montserrado & 108,366 & 1.54 & 16 & 90 & 8 & 16 & 0 \\
\hline Nimba & 62,862 & 1.05 & 80 & 78 & 22 & 6 & 3 \\
\hline River Cess & 3,436 & 1.70 & 84 & 77 & 5 & 1 & 1 \\
\hline Sinoe & 8,396 & 1.09 & 83 & 72 & 14 & 10 & 0 \\
\hline River Gee & 7,268 & 0.77 & 98 & 17 & 1 & 2 & 0 \\
\hline Gbarpolu & 13,753 & 0.93 & 83 & 33 & 3 & 3 & 1 \\
\hline Total & 352,708 & 1.22 & 71 & 67 & 10 & 9 & 1 \\
\hline
\end{tabular}

Source: FAO 2006; UNWFP - CFSNS 2006 


\section{Appendix B. Estimating Cash Crop Residues by County}

Considering that cash crops in Liberia, other than rubber and oil palm, are grown predominately on a range of small-, medium-, and large-scale production systems, the study uses a similar method for estimating the cash crop residues by county as the one described in Appendix A for food crops. Table 16 illustrates the number of farming families in Liberia growing different cash crops.

Table 16. Farming Families Growing Cash Crops in Liberia, 2005

\begin{tabular}{|c|c|c|c|c|c|c|c|c|}
\hline \multirow{2}{*}{ County } & \multirow{2}{*}{$\begin{array}{c}\text { Number of } \\
\text { Farming } \\
\text { Families }\end{array}$} & \multirow{2}{*}{$\begin{array}{l}\text { Average Farm } \\
\text { Size (ha) }\end{array}$} & \multicolumn{6}{|c|}{$\%$ of Farming Families Growing Cash Crops } \\
\hline & & & Sugarcane & $\begin{array}{l}\text { Bananas and } \\
\text { Plantains }\end{array}$ & Oil Palm & Coconut & Coffee & Cacao \\
\hline Bomi & 2,551 & 0.73 & 17 & 52 & 17 & 3 & 3 & 14 \\
\hline Bong & 37,736 & 1.42 & 21 & 26 & 17 & 1 & 9 & 26 \\
\hline Grand Bassa & 18,850 & 1.54 & 28 & 53 & 8 & 11 & 2 & 18 \\
\hline Grand Cape Mount & 4,572 & 1.13 & 0 & 18 & 49 & 18 & 15 & 18 \\
\hline Grand Gedeh & 11,515 & 1.13 & 0 & 38 & 4 & 2 & 13 & 72 \\
\hline Grand Kru & 2,945 & 0.77 & 27 & 65 & 5 & 12 & 1 & 20 \\
\hline Lofa & 31,477 & 2.19 & 2 & 12 & 10 & 0 & 82 & 53 \\
\hline Margibi & 24,117 & 1.21 & 14 & 34 & 14 & 14 & 0 & 10 \\
\hline Maryland & 14,864 & 1.13 & 33 & 50 & 4 & 9 & 2 & 19 \\
\hline Montserrado & 108,366 & 1.54 & 11 & 49 & 5 & 19 & 3 & 5 \\
\hline Nimba & 62,862 & 1.05 & 34 & 45 & 19 & 1 & 18 & 37 \\
\hline River Cess & 3,436 & 1.70 & 7 & 50 & 12 & 16 & 4 & 19 \\
\hline Sinoe & 8,396 & 1.09 & 8 & 59 & 17 & 21 & 8 & 29 \\
\hline River Gee & 7,268 & 0.77 & 1 & 64 & 5 & 19 & 4 & 54 \\
\hline Gbarpolu & 13,753 & 0.93 & 6 & 23 & 19 & 5 & 28 & 52 \\
\hline Total/Averaqe & 352,708 & 1.22 & 19 & 40 & 13 & 6 & 20 & 32 \\
\hline
\end{tabular}

Source: FAO 2006; UNWFP - CFSNS 2006

Rubber. Rubber residues are estimated on land occupied by large-scale plantations. As mentioned earlier, rubber residues generated by small-scale (household) farms are most likely used as firewood or in farm applications. The study estimates that large-scale rubber plantations in Liberia today cover an area of approximately 58,000 hectares. This land area was calculated using information from government publications and media releases, as summarized below.

In February 2008, the Liberian government signed a new lease agreement with Firestone on the 25,000 ha plantation in Margibi County through 2041. The government is also reviewing agreements with other rubber companies, including the 14,000 ha LAC, owned by Sofinco of Belgium, and the 10,000 ha Guthrie plantation, owned by Synergy Drive Bhd of Malaysia (Bax 2008). Salala Rubber Corporation will receive long-term financing from the International Finance Corporation (a member of the World Bank Group) to rehabilitate and expand its existing plantation of 40,000 ha in Margibi County, of which about 2,500 ha were planted before the war (Global Security 1985). Cavalla rubber plantation (about 4,000 ha) commenced production in May 2006 under the auspices of an interim management team led by the Rubber Planters Association of Liberia (RPAL) and Firestone (MOA 2007). Sinoe rubber plantation (approximately $2,200 \mathrm{ha}$ ) is currently exploited in an unsustainable fashion due to the "slaughter tapping" by illegal tappers, and the county has called for investments and incentives to reactivate production (Paye-Layleh 2004; Executive Mansion 2008). 
Oil Palm. Most palm oil is obtained from wild groves and because many of the state-owned plantations, largely abandoned during the war, were taken over by the local population for its own use, the study mainly considers small household production and it disaggregates it to county level using the approach described above. For industrial scale, state-owned plantations, the study estimates only the amount of residues that could be available during replanting (trunks and fronds). 


\section{Appendix C. Estimating Forest Residues by County}

Some of the existing and pending logging contracts spread over two or more counties, in which cases GIS and the information presented in Table 6 were used to disaggregate the total contracts' area to county level. Figure 11 illustrates the analysis methodology. Calculations are based on the areas suitable for FMCs and TSCs, and include lands that are outside of the national forests, existing and proposed protected areas.

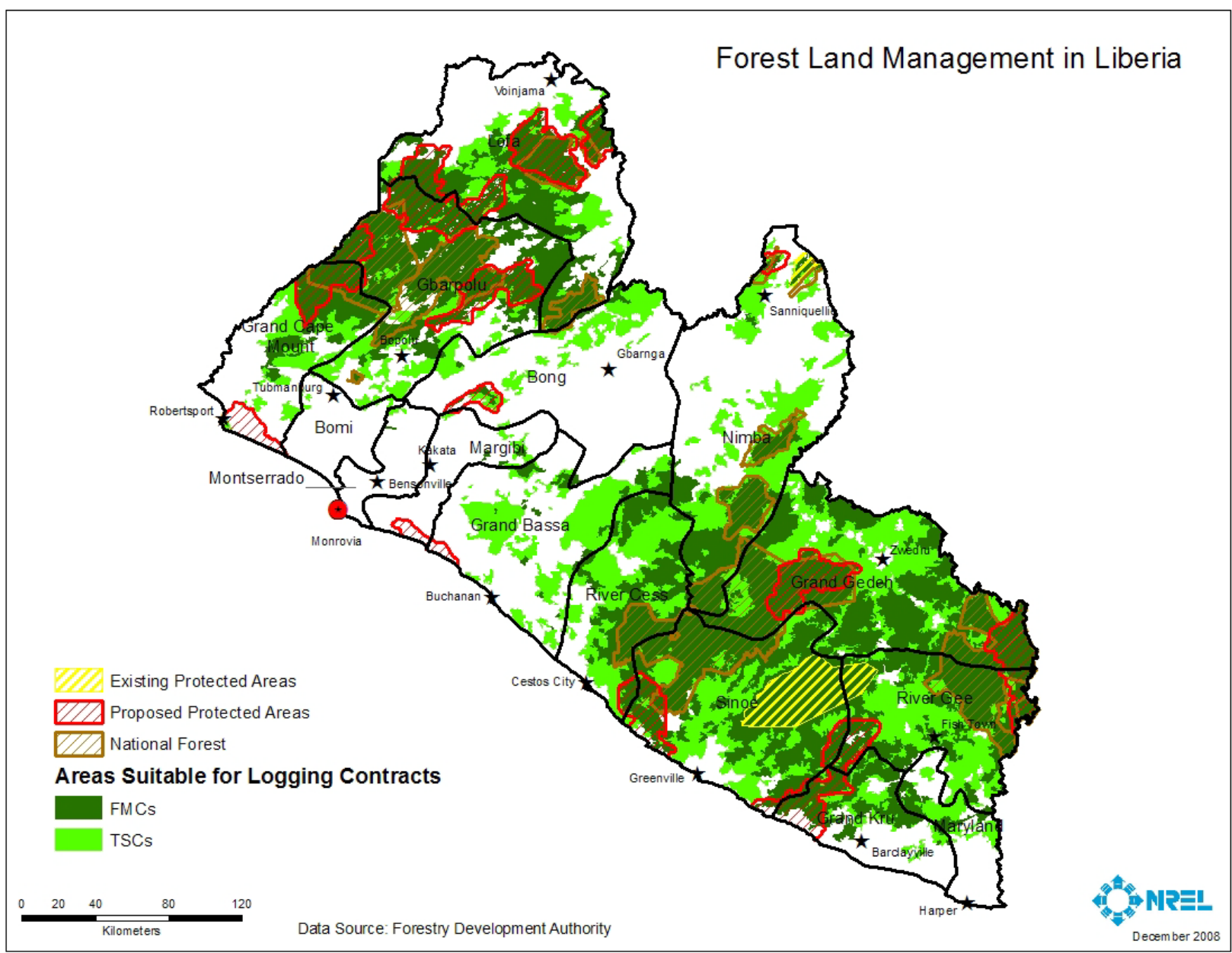

Figure 11. Forest Land Management in Liberia 


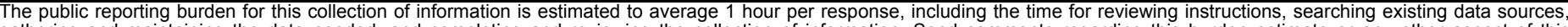

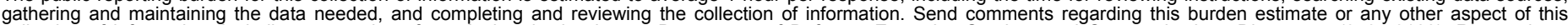

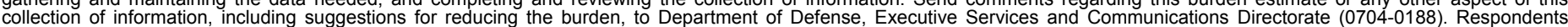

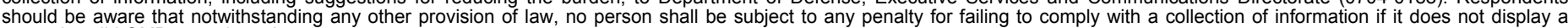

should be aware that notwithstanding

PLEASE DO NOT RETURN YOUR FORM TO THE ABOVE ORGANIZATION.

\begin{tabular}{l|l|l|l} 
1. REPORT DATE (DD-MM-YYYY) & 2. REPORT TYPE & 3. DATES COVERED (FrOm - TO)
\end{tabular} April 2009

Technical Report

4. TITLE AND SUBTITLE

Assessment of Biomass Resources in Liberia

5a. CONTRACT NUMBER

DE-AC36-08-GO28308

5b. GRANT NUMBER

5c. PROGRAM ELEMENT NUMBER

6. AUTHOR(S)

A. Milbrandt

5d. PROJECT NUMBER

NREL/TP-6A2-44808

5e. TASK NUMBER

WTD3.1000

5f. WORK UNIT NUMBER
7. PERFORMING ORGANIZATION NAME(S) AND ADDRESS(ES)

National Renewable Energy Laboratory

1617 Cole Blvd.

Golden, CO 80401-3393

9. SPONSORING/MONITORING AGENCY NAME(S) AND ADDRESS(ES)

\section{PERFORMING ORGANIZATION REPORT NUMBER \\ NREL/TP-6A2-44808}

10. SPONSOR/MONITOR'S ACRONYM(S) NREL

11. SPONSORING/MONITORING AGENCY REPORT NUMBER

12. DISTRIBUTION AVAILABILITY STATEMENT

National Technical Information Service

U.S. Department of Commerce

5285 Port Royal Road

Springfield, VA 22161

13. SUPPLEMENTARY NOTES

14. ABSTRACT (Maximum 200 Words)

Biomass resources meet about $99.5 \%$ of the Liberian population's energy needs so they are vital to basic welfare and economic activity. Already, traditional biomass products like firewood and charcoal are the primary energy source used for domestic cooking and heating. However, other more efficient biomass technologies are available that could open opportunities for agriculture and rural development, and provide other socio-economic and environmental benefits. The main objective of this study is to estimate the biomass resources currently and potentially available in the country and evaluate their contribution for power generation and the production of transportation fuels. It intends to inform policy makers and industry developers of the biomass resource availability in Liberia, identify areas with high potential, and serve as a base for further, more detailed site-specific assessments.

15. SUBJECT TERMS

NREL; Anelia Milbrandt; biomass; Liberia; biomass resources; biomass technologies; agriculture; rural development; transportation fuels; environmental benefits;

\begin{tabular}{|c|c|c|c|c|}
\hline \multicolumn{3}{|c|}{ 16. SECURITY CLASSIFICATION OF: } & \multirow{2}{*}{$\begin{array}{l}\text { 17. LIMITATION } \\
\text { OF ABSTRACT } \\
\text { UL }\end{array}$} & \multirow{2}{*}{$\begin{array}{l}\text { 18. NUMBER } \\
\text { OF PAGES }\end{array}$} \\
\hline $\begin{array}{l}\text { a. REPORT } \\
\text { Unclassified }\end{array}$ & $\begin{array}{l}\text { b. ABSTRACT } \\
\text { Unclassified }\end{array}$ & $\begin{array}{l}\text { c. THIS PAGE } \\
\text { Unclassified }\end{array}$ & & \\
\hline
\end{tabular}

19a. NAME OF RESPONSIBLE PERSON

19b. TELEPHONE NUMBER (Include area code) 